\title{
Foliage Biophysical Trait Prediction from Laboratory Spectra in Norway Spruce Is More Affected by Needle Age Than by Site Soil Conditions
}

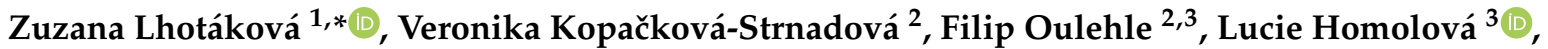 \\ Eva Neuwirthová ${ }^{1}$, Marian Švik ${ }^{3,4}$ (1) , Růžena Janoutová ${ }^{3}\left[\right.$ and Jana Albrechtová ${ }^{1}$ (1) \\ 1 Faculty of Science, Charles University, 12844 Prague, Czech Republic; eva.neuwirthova@natur.cuni.cz (E.N.); \\ jana.albrechtova@natur.cuni.cz (J.A.) \\ 2 Czech Geological Survey, 11821 Prague, Czech Republic; veronika.strnadova@geology.cz (V.K.-S.); \\ filip.oulehle@geology.cz (F.O.) \\ 3 Global Change Research Institute of the Czech Academy of Sciences, 60300 Brno, Czech Republic; \\ homolova.1@czechglobe.cz (L.H.); svik.m@czechglobe.cz (M.Š.); janoutova.r@czechglobe.cz (R.J.) \\ 4 Laboratory on Geoinformatics and Cartography, Department of Geography, Faculty of Science, Masaryk \\ University, 61137 Brno, Czech Republic \\ * Correspondence: zuzana.lhotakova@natur.cuni.cz
}

Citation: Lhotáková, Z;

Kopačková-Strnadová, V.; Oulehle, F.; Homolová, L.; Neuwirthová, E.; Švik, M.; Janoutová, R.; Albrechtová, J. Foliage Biophysical Trait Prediction from Laboratory Spectra in Norway Spruce Is More Affected by Needle Age Than by Site Soil Conditions. Remote Sens. 2021, 13, 391. https:// doi.org/10.3390/rs13030391

Received: 18 December 2020

Accepted: 20 January 2021

Published: 23 January 2021

Publisher's Note: MDPI stays neutral with regard to jurisdictional claims in published maps and institutional affiliations.

Copyright: (c) 2021 by the authors. Licensee MDPI, Basel, Switzerland. This article is an open access article distributed under the terms and conditions of the Creative Commons Attribution (CC BY) license (https:// creativecommons.org/licenses/by/ $4.0 /)$.

\begin{abstract}
Scaling leaf-level optical signals to the canopy level is essential for airborne and satellitebased forest monitoring. In evergreen trees, biophysical and optical traits may change as foliage ages. This study aims to evaluate the effect of age in Norway spruce needle on biophysical trait-prediction based on laboratory leaf-level spectra. Mature Norway spruce trees were sampled at forest stands in ten headwater catchments with different soil properties. Foliage biophysical traits (pigments, phenolics, lignin, cellulose, leaf mass per area, water, and nitrogen content) were assessed for three needle-age classes. Complementary samples for needle reflectance and transmittance were measured using an integrating sphere. Partial least square regression (PLSR) models were constructed for predicting needle biophysical traits from reflectance-separating needle age classes and assessing all age classes together. The ten study sites differed in soil properties rather than in needle biophysical traits. Optical properties consistently varied among age classes; however, variation related to the soil conditions was less pronounced. The predictive power of PLSR models was needle-age dependent for all studied traits. The following traits were predicted with moderate accuracy: needle pigments, phenolics, leaf mass per area and water content. PLSR models always performed better if all needle age classes were included (rather than individual age classes separately). This also applied to needleage independent traits (water and lignin). Thus, we recommend including not only current but also older needle traits as a ground truth for evergreen conifers with long needle lifespan.
\end{abstract}

Keywords: base cations; evergreen conifers; GEOMON; ground truth; leaf optical properties; partial least squares

\section{Introduction}

The physiological status of Norway spruce forests in Central Europe is currently affected by several abiotic and biotic stress factors. Some of them are connected with ongoing climate change such as increasing drought [1], especially during the summer, which, in combination with high temperatures, negatively affects spruce growth, particularly at low-elevation stands [2-4]. Natural abiotic disturbances including drought, temperature extremes, and windstorms can be followed by biotic ones: bark beetle attacks [5-7] or fungal infections [8] being the most common and currently most devastating agents in Norway spruce productive forests in Central Europe (e.g., summarized in [9]). Central European spruce forests also suffer from remarkable soil acidification, a heritage from past heavy air pollution loads resulting in large-scale Norway spruce forest decline [10-12]. 
In the 1990s, a network of small Norway spruce dominated stream catchments known as GEOMON (http:/ / www.geology.cz/geomon/english) was established in the Czech Republic to focus on biogeochemical monitoring of input-output element budgets $[13,14]$. The concentrations of the main 1980s pollutant, sulphur dioxide, have decreased considerably since the 1990s [15]; the atmospheric acid deposition was reduced and led to the recovery of stream water chemistry at small forested catchments [16]. Although there are apparent signs of ongoing soil recovery (e.g., increasing $\mathrm{pH}$ ), other parameters (low base cation to aluminum ratios) still indicate unfavorable conditions in the spruce rooting zone $[17,18]$. The GEOMON network provides a rich variety of data sources related to ecosystem functioning, focusing mainly on soil-stream water chemistry $[16,19,20]$, but recently also supporting the development of remote sensing solutions for forest recovery and biomass mapping [21,22]. This study further expands the breadth of GEOMON datasets by analyzing variability in Norway spruce optical properties and traits related to soil properties of different headwater catchments.

Nowadays, spatio-temporal changes in forest cover and forest health can be monitored via remote sensing optical methods [10,11,23-27]. Scaling of leaf-level properties to the canopy level is an essential component for the development of airborne and satellite-based tools for vegetation monitoring. Leaf optical properties reflect biochemical composition and structure [28-30] and thus provide information about the physiological status of an individual tree or forest stand [25]. Furthermore, canopy optical signals have recently been used for the estimation of soil properties [31,32]. Some attempts have been made using Eucalyptus grandis canopy spectra for soil carbon estimation [33] or spectral chlorophyll indices of Picea rubens and Abies balsamea to predict the dissolved organic $\mathrm{C}$ and $\mathrm{N}$ of forest soils [34]; though, to our knowledge, such attempts usually had a case-study character.

Coniferous species of the Pinaceae family, such as Norway spruce (Picea abies (L.) H. Karst.) and Scots Pine (Pinus sylvestris L.), are very common and widespread in European forests. Therefore, when using leaf optical properties for forest health assessments, the challenges brought on by conifers' leaf longevity, needle structure, and shoot architecture for vegetation spectroscopy and remote sensing applications should be taken into account [35]. To contribute to these topical issues, in the present study we focused on the effect of needle age on its biophysical and optical properties in Norway spruce. It is well known that conifer needles change their biochemical composition with age, usually accumulating photosynthetic pigments [36,37], secondary metabolites (e.g., phenolic compounds [38,39]) and dry mass in general [40]. On one hand, some mobile elements (e.g., nitrogen, phosphorus, magnesium) can be retrieved from current biochemical compounds and redistributed from older to younger needles in case of soil nutrient scarcity. On the other hand, less mobile nutrients which play preferentially structural roles (e.g., calcium) accumulate with needle age and thus cannot be efficiently re-distributed [41-43]. The structural and biochemical changes during needle lifespan are, to some extent, reflected in changes in needle optical properties [35]. In addition to needle age, other factors cause within-crown variability in needle biophysical and optical properties; the vertical light gradient being the most influential $[36,44,45]$ and the cardinal direction branch orientation almost negligible $[46,47]$. However, in the present study, we focused primarily on the variability in needle traits imposed by needle age in the crown part most related to canopy remote sensing and thus analyzed only the upper sunlit branches in a productive part of a crown.

There is not a consensus in the remote sensing community on how to deal with needles developed in different seasons (needle age classes, NACs) while taking biophysical and leaf level optical measurements as ground truth. Some remote sensing and spectroscopic studies use only one needle age class, usually the youngest one, i.e., the needles developed in the current vegetation season (NAC1, e.g., [48,49]); however, in other cases, more needle age classes are analyzed, e.g., [10,50,51]. On one hand, current year needles (NAC1) and one-year old needles (NAC2) are the most photosynthetically active in the canopy of several conifers $[40,52-54]$ and, therefore, they should well reflect trees' physiological status. On the other hand, the remote optical signal acquired at the canopy level is derived from more 
needle age classes than only the current and previous-year needles (NAC1 and NAC2). Moreover, with increasing spatial resolution of UAV-borne, airborne, and even satellite acquired data to a sub-canopy scale, knowledge of age dependency of the biophysical and optical needle traits is becoming more important.

The present study aims to provide deeper insight into needle-age related variability of foliage biophysical and optical traits in conifers with long-living needles. The main goal was to evaluate the effect of Norway spruce needle age on biophysical traits predictions based on laboratory leaf-level spectra and to make recommendations on how to deal with needle age classes while taking ground truth. We hypothesize that age-dependence of needle traits influence the power of prediction models. In line with this, we first examined how the measured needle biophysical traits and optical properties change with needle aging, and second, how they vary between sites (characterized by soil properties). Finally, we evaluated the power of partial least square regression (PLSR) models of needle biophysical traits, including different needle age classes separately and together. The secondary goal was to evaluate if separation of Norway spruce-forested catchments is driven by needle biophysical traits or by site conditions (i.e., soil properties).

\section{Materials and Methods}

\subsection{Description of Study Sites}

The forested headwater catchments (median size of $62 \mathrm{ha}$ ) dominated by Norway spruce (Picea abies L. Karst) were selected for the study (catchment characteristics are summarized in Table 1, location, and sampling design in Figure 1). All sites are part of the GEOMON network (established in 1994) that primarily focuses on biogeochemical monitoring of various ecosystem elements, atmospheric deposition, and output by surface runoff $[13,14,16]$. Most of the catchments are covered by managed Norway spruce monoculture over 40 years old; the only exceptions are UDL and UHL sites, which were completely deforested due to heavy acid depositions loads in the 1980s; therefore, the spruce stands there are younger (21-40 years).

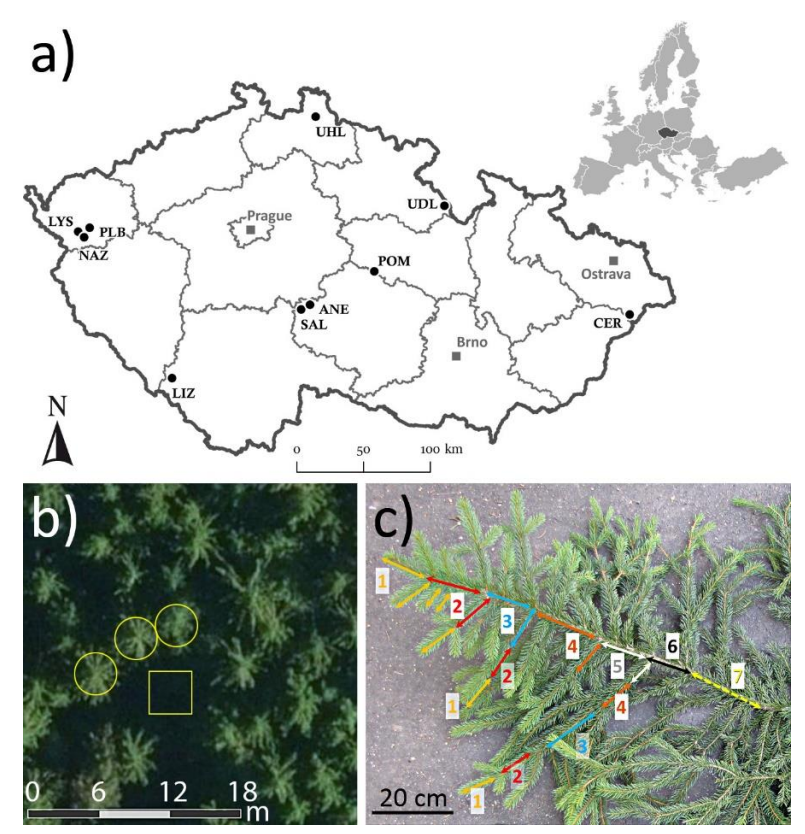

Figure 1. Study site location; soil, tree, and needle sampling design. (a) Location of ten GEOMON catchments under study in the Czech Republic; (b) design of soil and tree sampling: square-soil pit, circles-three sampled Norway spruce trees adjacent to a soil pit; (c) individual needle age classes (NAC) on Norway spruce branch, NAC 1 and 2 were sampled separately to represent young potosyntehtically active needles, NAC3 was not sampled, four to seven seasons old needles were pooled and labeled as NAC4 to represent older less active needles. 
Table 1. Characteristics of ten GEOMON headwater catchments in the present study.

\begin{tabular}{|c|c|c|c|c|c|c|c|c|c|c|c|c|}
\hline $\begin{array}{l}\text { Catchment } \\
\text { Name }\end{array}$ & Code & $\begin{array}{l}\text { Elevation } \\
\text { (m a.s.1.) }\end{array}$ & $\begin{array}{c}\text { Area } \\
\text { (ha) }\end{array}$ & Bedrock & Soils & $\begin{array}{c}\text { Forest Cover } \\
\text { Conifer/Broadleaved } \\
(\%)\end{array}$ & $\begin{array}{l}\text { Forest Age } \\
(y r)\end{array}$ & $\begin{array}{l}\text { Mean } \\
\text { Temper- } \\
\text { ature } \\
\left({ }^{\circ} \mathrm{C}\right)\end{array}$ & $\begin{array}{c}\text { Mean } \\
\text { Precipitation } \\
(\mathrm{mm})\end{array}$ & $\begin{array}{c}\text { Forest } \\
\text { Floor } \mathbf{p H}\end{array}$ & $\begin{array}{l}\text { Mineral } \\
\text { Soil pH }\end{array}$ & $\begin{array}{c}\text { Forest } \\
\text { Floor C/N }\end{array}$ \\
\hline $\begin{array}{l}\text { Anenský } \\
\text { potok }\end{array}$ & ANE & $486-546$ & 26 & Paragneiss & $\begin{array}{l}\text { Cambisols, } \\
\text { Stagnic } \\
\text { Cambisols }\end{array}$ & $85 / 2.6$ & $40-60$ & 8.3 & 673 & 4.00 & 4.67 & 22.1 \\
\hline Červík & CER & $637-961$ & 181 & $\begin{array}{l}\text { Sandstone, } \\
\text { Claystone }\end{array}$ & $\begin{array}{l}\text { Cambisols, } \\
\text { Stagnosols } \\
\text { Cambisosl }\end{array}$ & $91 / 3$ & $40-60$ & 6.8 & 1212 & 3.40 & 4.13 & 21.2 \\
\hline Liz & LIZ & $827-1070$ & 94 & Paragneiss & $\begin{array}{l}\text { Dystric } \\
\text { Cambisols }\end{array}$ & $84 / 8.5$ & $60-100$ & 6.1 & 892 & 3.50 & 4.38 & 24.3 \\
\hline Lysina & LYS & $828-943$ & 27 & Granite & $\begin{array}{l}\text { Cambisols, } \\
\text { Podzols }\end{array}$ & $93 / 0.5$ & $40-60$ & 6.3 & 1005 & 3.37 & 4.33 & 26.0 \\
\hline Na zeleném & NAZ & 733-802 & 60 & Amphibolite & Cambisol & $79 / 4.6$ & $60-100$ & 6.8 & 857 & 3.86 & 5.07 & 26.0 \\
\hline Pluhův bor & PLB & $690-796$ & 22 & Serpentinite & $\begin{array}{l}\text { Magnesic } \\
\text { Cambisols }\end{array}$ & $69 / 0.6$ & $60-100$ & 6.8 & 861 & 3.85 & 5.82 & 30.8 \\
\hline Polomka & $\mathrm{POM}$ & $554-650$ & 66 & $\begin{array}{l}\text { Paragneiss, } \\
\text { Orthogneiss }\end{array}$ & $\begin{array}{l}\text { Cambisols, } \\
\text { Gleysols }\end{array}$ & $87 / 7$ & $60-80$ & 7.7 & 697 & 3.77 & 4.37 & 24.7 \\
\hline $\begin{array}{c}\text { Salačova } \\
\text { Lhota }\end{array}$ & SAL & $560-745$ & 200 & Paragneiss & $\begin{array}{l}\text { Cambisols, } \\
\text { Stagnic } \\
\text { Cambisols }\end{array}$ & $88 / 4.6$ & $60-80$ & 7.6 & 675 & 3.46 & 4.30 & 29.4 \\
\hline Uhliřrská & UHL & $776-885$ & 180 & $\begin{array}{c}\text { Granite, } \\
\text { Granodiorite }\end{array}$ & $\begin{array}{c}\text { Entic } \\
\text { Podzols, } \\
\text { Distric } \\
\text { Cambisols }\end{array}$ & $86 / 0.3$ & $20-40$ & 5.6 & 1250 & 3.50 & 4.33 & 21.5 \\
\hline Data source: & & $\begin{array}{l}\text { DEM } \\
\text { 5G-digital } \\
\text { elevation } \\
\text { model } 2020\end{array}$ & DEM 5G & [16] & [16] & $\begin{array}{l}\text { Classified from } \\
\text { CASI airborne } \\
\text { images }\end{array}$ & [16] & $\begin{array}{c}\text { Oulehle } 2020 \\
\text { pers. comm. } \\
\text { Mean } \\
\text { 1994-2019 }\end{array}$ & $\begin{array}{c}\text { Krám } 2019 \\
\text { pers. comm. }\end{array}$ & & & \\
\hline
\end{tabular}




\subsection{Soil Sampling and Analyses}

Soil sampling was conducted at GEOMON catchments in 2015. At each catchment, 5-15 sampling pits were excavated, forest floor and mineral soil were sampled and processed as described in [55]. Only the results of pooled samples of the fermentation and humus horizons are used in the present study, reported as FH horizon soil properties. Exchangeable cations in soils were analyzed in $0.1 \mathrm{M} \mathrm{BaCl}_{2}$ extracts by flame atomic absorption spectrophotometry (FAAS, AAnalyst Perkin Elmer 100, Perkin Elmer, Waltham, MA, USA). Furthermore, available $\mathrm{Ca}, \mathrm{Mg}$, K (FAAS) and $\mathrm{P}$ (spectrophotometry) were determined in Mehlich extracts. Total content of base cations (FAAS) and P (spectrophotometry) were analyzed after acid digestion of ash after sample combustion $\left(350{ }^{\circ} \mathrm{C}\right)$. Exchangeable acidity was determined by titration of the $0.1 \mathrm{M} \mathrm{BaCl}_{2}$ extracts. Cation exchange capacity (CEC) was calculated as the sum of exchangeable base cations and exchangeable acidity. Base saturation (BS) was determined as the fraction of CEC associated with base cations. The following parameters of $\mathrm{FH}$ horizon were used for data analysis: exchangeable acidity- $\mathrm{Al}+\mathrm{H}\left(\right.$ meq kg $\left.^{-1}\right)$; base saturation- $\mathrm{BS}$ [\%]; $\mathrm{pH}$ in water and in $\mathrm{KCl}$; exchangeable base cations $\left(\mathrm{BaCl}_{2}\right)$ of $\mathrm{Ca}_{\mathrm{ex}}, \mathrm{K}_{\mathrm{ex}}, \mathrm{Mg}_{\mathrm{ex}}\left(\mathrm{mg} \mathrm{kg}^{-1}\right)$; available $\mathrm{Ca}_{\text {avail }}, \mathrm{K}_{\text {avail }}$, $\mathrm{Mg}_{\text {avail }}$ and $\mathrm{P}_{\text {avail }}$ (Mehlich) ( $\left.\mathrm{mg} \mathrm{kg}^{-1}\right)$; and total $\mathrm{Ca}_{\text {tot }}, \mathrm{K}_{\text {tot }}, \mathrm{Mg}_{\text {tot }}$ and $\mathrm{P}_{\text {tot }}$ (total digest) $\left(\mathrm{mg} \mathrm{kg}^{-1}\right)$ and $\mathrm{C}: \mathrm{N}$ ratio $\left(\mathrm{g} \mathrm{g}^{-1}\right)$. Soil organic $\mathrm{C}$ and $\mathrm{N}$ were measured simultaneously using a Thermo Scientific Flash 2000. For descriptive statistics of selected FH horizon properties see Supplementary Table S1.

\subsection{Needle Sampling and Analyses}

An extensive field campaign at ten GEOMON sites was conducted during 2-23 August 2017. The needle sampling was conducted during sunny days with minimum clouds and was synchronized with acquisition of airborne hyperspectral data (not used in the present study). Actual weather conditions (daily mean temperature, daily mean relative humidity and daily precipitation) are shown in Supplementary Figure S2. In total, 123 Norway spruce trees were sampled, 9-15 trees per site, always with 3 trees adjacent to a soil sampling pit (Figure 1b). None of the sampled trees exhibited any visual damage at the time of sampling and held at least 6-8 needle age classes, which corresponds to a healthy tree. One branch from the sun exposed production crown part was collected from each tree by a tree climber and transported to a laboratory. Samples for three needle age classes were taken for laboratory spectroscopy measurements and assessment of needle biophysical traits (Figure 1c): current needle age class (NAC1) represents needles developed in 2017 growing season, thus, less than one year old needles at the time of sampling; previous year needle age class (NAC2) represents needles developed in 2016 growing season-almost two years old needles at the time of sampling and a mixed sample of 4-6 years old needles (NAC4) developed in 2014 and earlier. On one hand, NAC1 and NAC2 represented young photosynthetically active foliage [40,52-54]. On the other hand, NAC4 represented rather older, less active needles. Three-year-old needles (NAC3) were not sampled to keep the number of samples reasonable for processing time. Needle sampling and spectroscopic measurements were always conducted not later than $48 \mathrm{~h}$ after the branch cutting.

\subsubsection{Needle Spectra Acquisition and Preprocessing}

Needle directional-hemispherical reflectance factor (DHRF) and directionalhemispherical transmittance factor (DHTF) between 350 and $2500 \mathrm{~nm}$ were measured using an ASD FieldSpec 4 Wide-Res portable spectroradiometer (Malvern Panalytical, Malvern, UK) attached to an ASD RTS-3ZC integrating sphere (Malvern Panalytical, Malvern, UK). The measurements of needle optical properties were done according to protocols used in previous studies [56,57]. Immediately before the spectra measurement, needles were detached from shoots and arranged to specifically designed carriers, which make it possible to place needles close to each other with small gaps to cover the field of view of the integrating sphere [56,57]. The geometry between the sample, light source and spectroradiometer is, therefore, given for reflectance and transmittance measurements by the configuration 
of sample ports in the integrating sphere. Distance between a needle sample and a light source varies for the reflectance and transmittance configuration, which causes different portions of a needle sample to be illuminated. The illumination zone for the reflectance and transmittance of the sample was captured by taking a digital photograph of a blank paper placed in the illuminated sample port. The proportion of gaps (gap fraction, GF) between needles within the field of view of the integrating sphere was computed from scans of needles in the carriers by applying a mask of the actual light beam position in the sample port. Equations (1) and (2) show the computation of final DHRF and DHTF:

$$
\begin{gathered}
\text { DHRF }=\frac{\frac{\left(R_{\text {sample }}-R_{\text {stray }}\right) \times R_{\text {is }}}{W R-R_{\text {stray }}}}{1-\mathrm{GF}_{\mathrm{R}}} \\
\text { DHTF }=\frac{\frac{\left(\mathrm{T}_{\text {sample }}\right)}{\mathrm{WR}-\mathrm{R}_{\text {stray }}}-\mathrm{R}_{\mathrm{is}} \mathrm{GF}_{\mathrm{T}}}{1-\mathrm{GF}_{\mathrm{T}}}
\end{gathered}
$$

$\mathrm{R}_{\text {sample }}$ and $\mathrm{T}_{\text {sample }}$ correspond to reflectance and transmittance, respectively, of needles measured in digital number (DN) values, $R_{\text {stray }}$ is stray light in DN values, $R_{i s}$ is reflectance of the inner sphere wall, $W R$ is a white reference reflectance measured in DN values and $\mathrm{GF}_{\mathrm{R}}$ and $\mathrm{GF}_{\mathrm{T}}$ is computed gap fraction for the reflectance and transmittance sample, respectively. All spectra were smoothed out using a filter based on weighted linear least squares and a 2nd degree polynomial model and a filter window width of $41 \mathrm{~nm}$ (smooth "rloess" function in Matlab R2018b). Spectra below 450 and above $2000 \mathrm{~nm}$ were too noisy and, therefore, were not used for principal component analysis (PCA) and PLSR modeling. Unfortunately, transmittance measurements of needle leaf objects are often affected by gaps between needles placed in the sample port, which produces negative transmittance values in the visible wavelengths (e.g., [58-60]). This was also the case of our samples and those samples were corrected by applying an offset computed from the minimum transmittance value in the red region. Therefore, needle transmittance spectra were used only to illustrate differences among NAC1, NAC2 and NAC4 and were not used for trait modeling.

\subsubsection{Assessment of Needle Biophysical Traits}

Photosynthetic pigments (chlorophyll a and $\mathrm{b}-\mathrm{Cab}$; total carotenoids-Car) were extracted in dark conditions, at $4{ }^{\circ} \mathrm{C}$ for seven days with $N, N$-dimethylformamide [61] and their content was determined spectrophotometrically. Pigment concentrations were calculated according to the equations reported by [62] and related to the unit of dry matter. Another set of needle samples was used for fresh and dry weight assessment and computation of water content as the equivalent of mass reduction after needle drying. After homogenizing dry needles, total soluble phenolic compounds were extracted in $80 \%$ methanol and determined spectrophotometrically using a Folin-Ciocalteau phenol reagent and gallic acid as a standard [63]. Lignin content was assessed by thioglycolate solubilization [64] and then determined spectrophotometrically at a wavelength of 280 $\mathrm{nm}$ using hydrolytic lignin (Aldrich Chemical Company, USA; [8672-93-3]) as a standard. Cellulose content was analyzed after Loader et al. [65] from pellets after lignin extraction, which was repeatedly washed with $17 \% \mathrm{NaOH}$, dried and related to the original dry weight. Oven-dried needles were homogenized and used for determination of $\mathrm{C}$ and $\mathrm{N}$ contents and their mass ratio. Total $\mathrm{C}$ and $\mathrm{N}$ were determined simultaneously using a Thermo Scientific Flash 2000 analyzer (Thermo Fisher Scientific, Waltham, MA, USA).

Needles used for the optical properties measurements were removed from the carrier, scanned for projection area and their hemi-surface area was calculated according to [36]. Needles were afterward dried at $80{ }^{\circ} \mathrm{C}$ to a constant weight and the leaf mass per area (LMA, $\mathrm{g} \mathrm{cm}^{-2}$ ) was determined. LMA was used for conversion of other needle traits (Cab, Car, water soluble phenolic compounds, lignin, and cellulose) contents to area-based units. 


\subsection{Statistical Analyses and PLSR Modeling}

Variation in leaf traits among the catchments and due to needle age classes were tested by two-way ANOVA with needle age and catchment as fixed factors. Differences were considered significant at $\alpha=0.05$. ANOVA was performed by NCSS 9 software (NCSS, LCC Kaysville, UT, USA).

Principal component analysis (PCA) was applied on needle traits and catchment soil properties. Three separate models were created. Each model included needle traits from one needle age class (NAC1, NAC2 and NAC4) and FH horizon soil properties. Needle traits were averaged for three sampled trees adjacent to the individual soil pit. In total, 41 samples for each variable entered the model.

Visualization of leaf optical properties and the differences among NAC1, NAC2 and NAC4 were performed in Matlab R2018b. Differences among needle age classes in spectral range $450-2000 \mathrm{~nm}$ were tested by linear mixed-effect model, with nested tree effect. Linear mixed-effect model was performed in R (4.0.3), using the package "nlme" [66].

For the purpose of separating sites and needle age classes from needle spectra, PCA was applied also on needle reflectance and transmittance spectra to reduce dimensionality and reveal if there is any structure in needle spectra related to needle age or catchment. Principal Component Analysis was based on the NIPALS algorithm [67], the model was cross-validated with random 20 segments. PCA was conducted for needle reflectance and transmittance separately, including spectra from all catchments and needle age classes.

Prediction models for selected needle traits were established, using PLSR analysis with the same NIPALS algorithm as the PCA. For each model, the following input variables were used: the measured needle spectra (DHRF between 400 and $2000 \mathrm{~nm}$ ) represented independent variables $\mathrm{X}$ and the needle traits were then dependent variables $\mathrm{Y}$. Using the measured reflectance spectra, the individual PLSR models were computed for numerous needle traits.

The PLSR modeling included the standard calibration and the validation stages $[68,69]$. To assess the model performance, a random-cross-validation was conducted. The models were evaluated based on the standard measures [70,71], such as: the lowest number of factors (a measure of model robustness), the lowest root mean square error of prediction (RMSEP), and the coefficient of determination $\left(\mathrm{R}^{2}\right)$. Both PCA and PLSR modeling were performed in Unscrambler 11 (CAMO Analytics, Oslo, Norway).

\section{Results}

\subsection{Needle Biophysical Traits-Age Effects}

Needle pigments (Cab and Car) including their ratio Car:Cab, phenolic compounds (Figure 2) and dry mass (LMA-Figure 3a) on an area basis showed a very strong effect of needle age, accumulating the compounds in older needles. This pattern was significant and consistent at all GEOMON sites. Needle nitrogen content was age-dependent too (Figure $3 \mathrm{e}, \mathrm{f})$. The $\mathrm{N}$ content decreased, usually in NAC 4 needles, probably due to dilution by accumulating structural compounds or due to translocation to younger tissues. The only exception in this pattern was the PLB site showing the accumulation of $\mathrm{N}$ in older needles instead. The C:N ratio increased usually towards older needles and confirmed the nitrogen dilution effect by accumulating dry mass. There was a group of needle traits independent of needle age: water, cellulose, and lignin contents (Figure 3a-d). 
a)

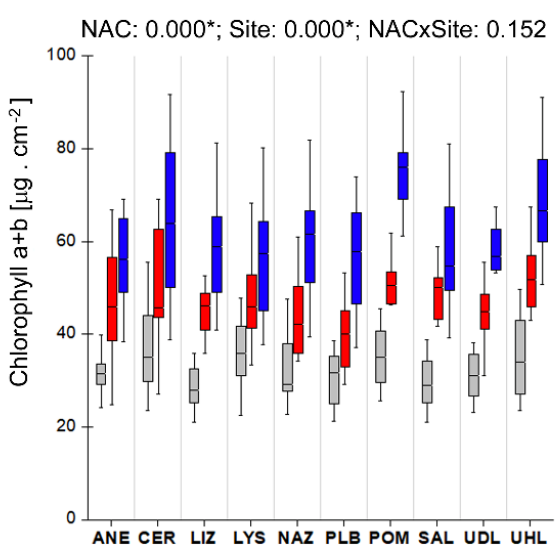

c)

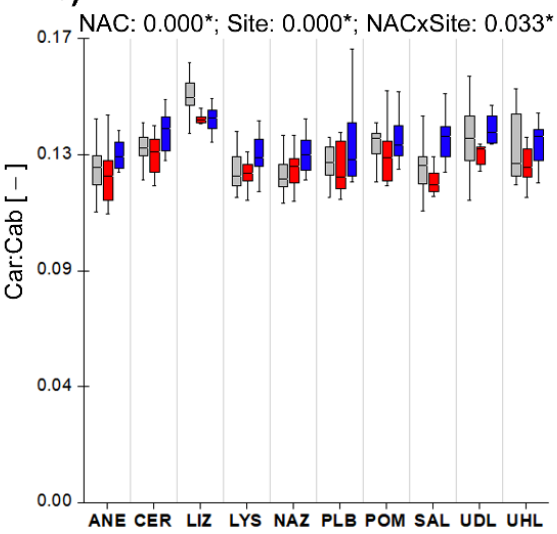

b)



d)

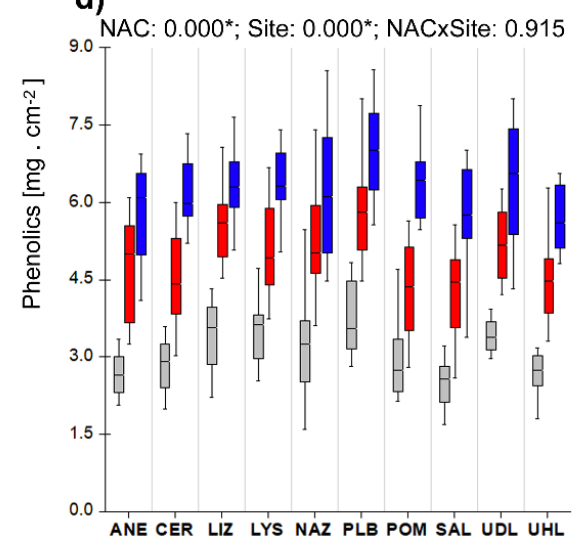

Figure 2. Needle traits according to their needle age and site location corresponding to different headwater catchments (see description in Table 1). (a) Chlorophyll $a+b$ content; (b) total carotenoids content; (c) the ratio of total carotenoids to chlorophylls (Car:Cab); (d) soluble phenolics content in needles at ten GEOMON sites (ANE, CER, LIZ, LYS, NAZ, PLB, POM, SAL, UDL and UHL). NAC—needle age class: 1—current year needles; 2-previous year needles; 4 -four year and older needles. Two-way ANOVA, effect of needle age, site, and their interaction (NAC x Site): $p$-values; *-significant at $\alpha=0.05$.

\subsection{Variation among the GEOMON Catchments in Needle Traits and Soil Properties}

Principal component analysis (PCA) showed that the GEOMON catchments differ mainly by their soil properties; the needle traits showed less influence in the model (Figure 4). Score plots of PCA models based on needle traits for three different needle age classes showed a very similar separation of GEOMON catchments. Roughly, we could distinguish three groups of catchments based mainly on their exchangeable acidity in FH horizon, needle nitrogen content, base saturation, and calcium and magnesium concentration in FH horizon (Figure $4 \mathrm{a}, \mathrm{c}, \mathrm{e}$ ). The first group with high exchangeable acidity, high $\mathrm{N}$ needle content and low $\mathrm{Ca}$ and $\mathrm{Mg}$ included three catchments: UHL, CER, LYS. Four catchments-LIZ, UDL, POM, SAL-localized scores position closer to the coordinates' center, exhibiting rather moderate values of exchangeable acidity, $\mathrm{N}$ needle content and $\mathrm{Ca}$ and Mg in FH horizon. Finally, catchments ANE, NAZ and PLB formed the third group, showing higher $\mathrm{C}: \mathrm{N}$ ratio, higher $\mathrm{Ca}$ and $\mathrm{Mg}$ content, higher base saturation and low exchangeable acidity in the FH horizon. 
a)



c)

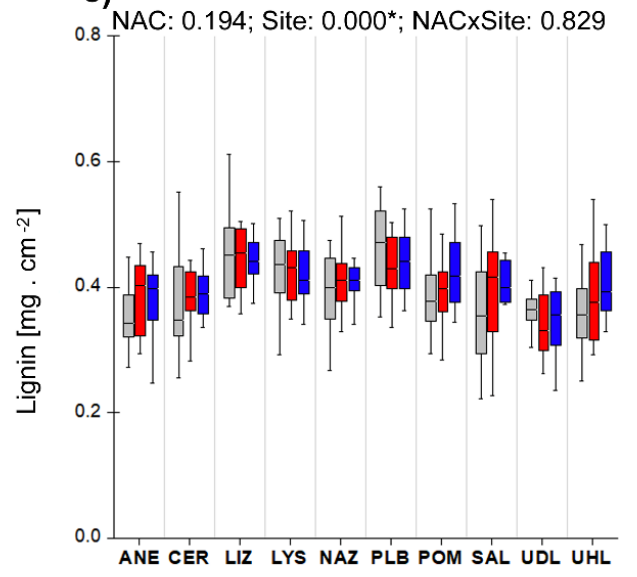

e)



b)

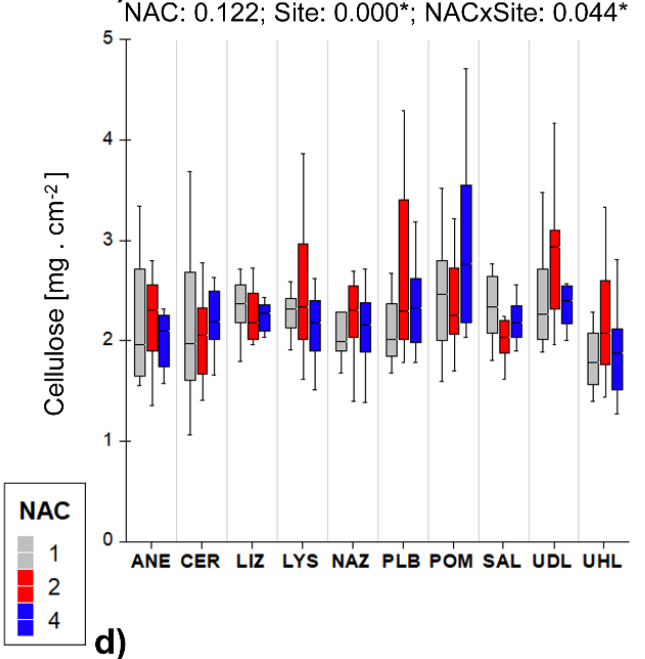

NAC: 0.734 ; Site: $0.000^{*}$; NACxSite: 0.517

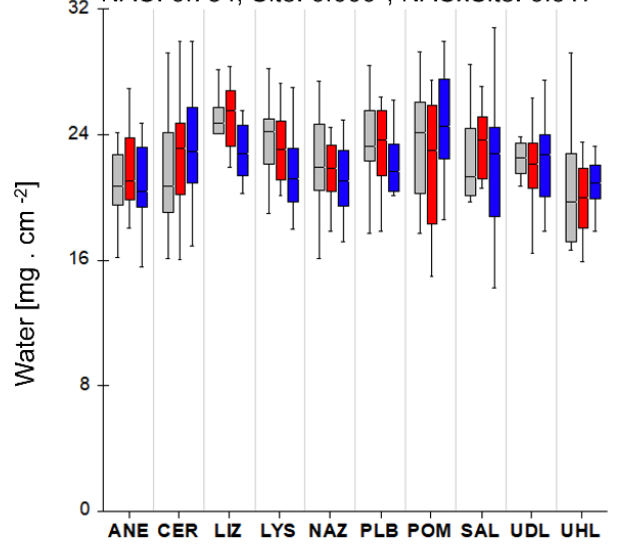

f)

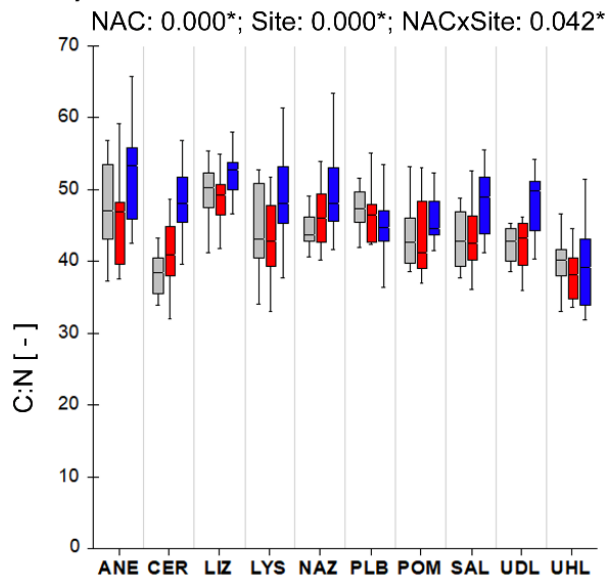

Figure 3. Needle traits according to their needle age and site location corresponding to different headwater catchments (see description in Table 1). (a) Leaf dry mass per area (LMA); (b) cellulose content; (c) lignin content; (d) water content; (e) nitrogen content (\% of dry mass); (f) C:N ratio in needles at ten GEOMON sites (ANE, CER, LIZ, LYS, NAZ, PLB, POM, SAL, UDL and UHL). NAC—needle age class: 1 -current year needles; 2-previous year needles; 4-four year and older needles. Two-way ANOVA, effect of needle age, site, and their interaction (NAC x Site): $p$-values; *-significant at $\alpha=0.05$. 
Scores

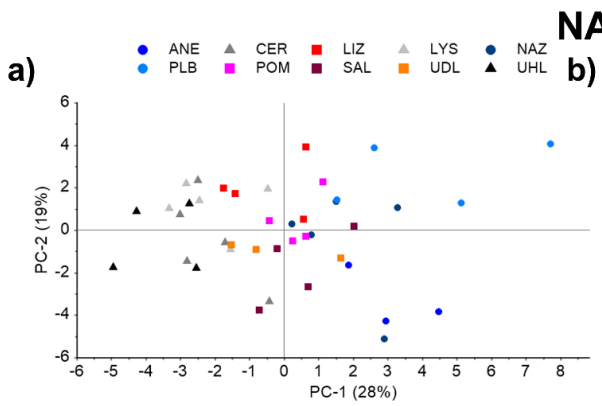

Loadings

AC 1

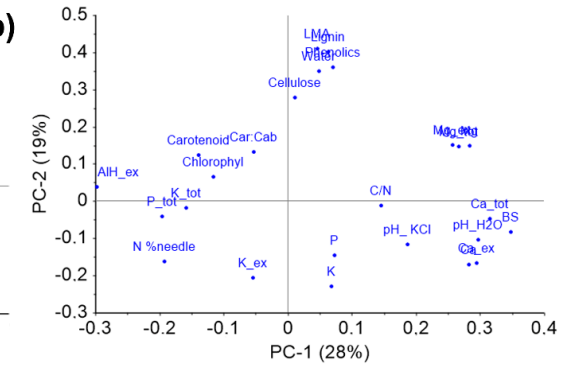

NAC 2
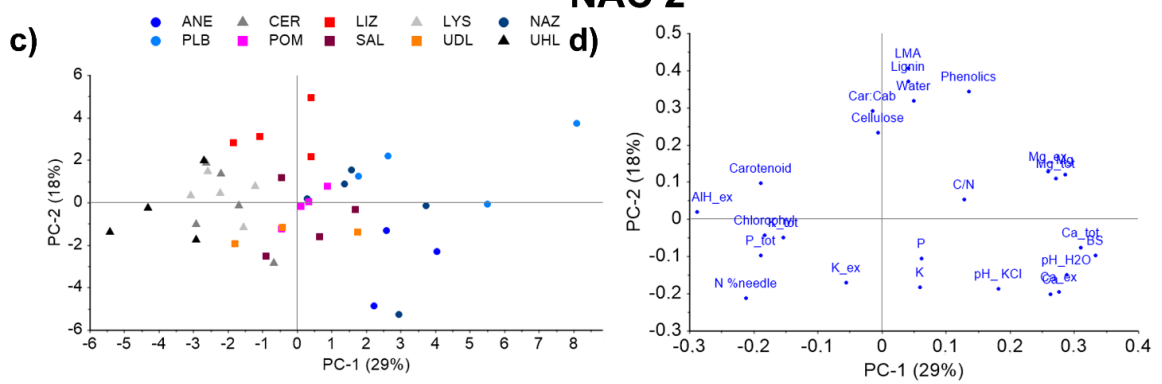

NAC 4
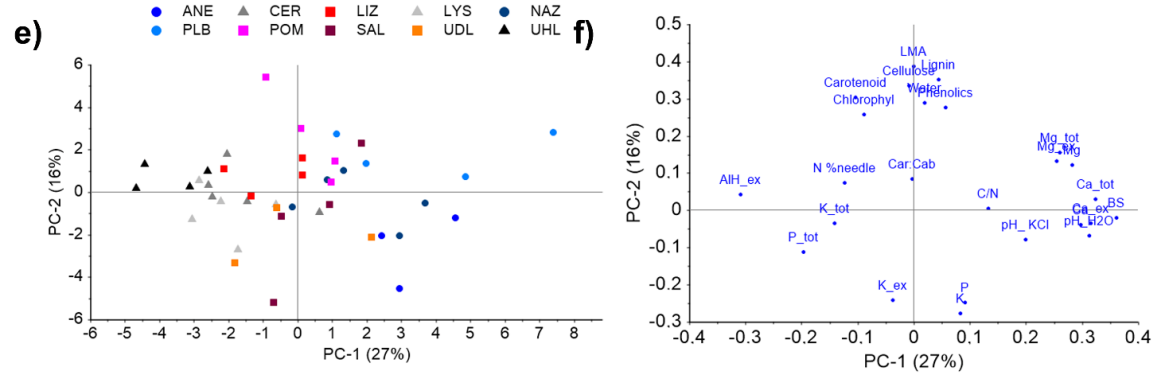

Figure 4. Score plots and loadings plots for PCA applied on needle traits and FH horizon soil properties of GEOMON catchments (for site description see Table 1). For each model, the needle traits from one needle age class were included: $(\mathbf{a}, \mathbf{b}) \mathrm{NAC} 1 ;(\mathbf{c}, \mathbf{d}) \mathrm{NAC} 2 ;(\mathbf{e}, \mathbf{f}) \mathrm{NAC} 4$. Needle traits: Carotenoids—total carotenoids content; Chlorophyll—total chlorophyll content; Lignin—lignin content; Phenolics—content of total soluble phenolics; Water-water content; LMA—leaf mass per area; Car:Cab - total carotenoids to total chlorophyll ratio; N\% needle-needle nitrogen content related to dry mass. Soil properties: $\mathrm{AlH}$ _ex —-total exchangeable acidity; $\mathrm{pH} \_\mathrm{KCl}, \mathrm{pH} \_\mathrm{H} 2 \mathrm{O}-\mathrm{pH}$ assessed in $\mathrm{KCl}$ and water, respectively; $\mathrm{BS}$ - base saturation; $\mathrm{Ca}$ _ex, $\mathrm{K} \_$ex, $\mathrm{Mg}$ _ex-exchangeable base cations ( $\mathrm{BaCl} 2)$; $\mathrm{Ca}, \mathrm{K}, \mathrm{Mg}$, P available $\mathrm{Ca}, \mathrm{K}, \mathrm{Mg}, \mathrm{P}$ (Mehlich); Ca_tot, $\mathrm{K} \_t o t, \mathrm{Mg}$ tot and P_tot-total $\mathrm{Ca}, \mathrm{K}, \mathrm{Mg}, \mathrm{P}$ (total digest); $\mathrm{C} / \mathrm{N}-\mathrm{C}: \mathrm{N}$ ratio in $\mathrm{FH}$ horizon.

PC1, driven particularly by exchangeable acidity, total phosphorus content, $\mathrm{pH}$, base saturation, and content of base cations (their exchangeable and total pools) accounted for $28 \%( \pm 1 \%)$ of total variation for NAC1, NAC2 and NAC4 (Figure 4$)$. The PC2 accounted for 19,18 and $16 \%$ of variation for NAC1, NAC2 and NAC4, respectively, driven mainly by the needle traits (Figure $4 b, d, f$ ). The most influential needle traits in PC2 were LMA, lignin, phenolics, water and cellulose, consistently for all models regardless of needle age. Position of chlorophyll, total carotenoids and their ratio in loading plots varied among models for individual needle age classes: In the model based on needle traits of NAC1, both pigments contributed to both PC1 and PC2 (Figure 4b). In the model based on needle traits of NAC2, carotenoid and chlorophyll content contributed preferentially to PC1 in contrast to their ratio contributing only to PC2 (Figure 4d). Finally, the model based on needle traits of NAC4 exhibited carotenoid and chlorophyll contribution mainly to PC2 with other needle traits (Figure 4f). 
The first two components explained $47 \%$ of total variation if modeled for NAC1 and NAC2; $43 \%$ if modeled for NAC4. In total, 7 components were included in the PCA models and together they explained 86,86 and $85 \%$ of total data variation if modeled from needle traits for NAC1, NAC2 and NAC4, respectively. The percentage of variation explained by PCs 3-7 was very similar for models of all needle age classes.

\subsection{Needle Optical Properties}

Needle optical properties_-reflectance and transmittance (DHRF and DHTF)—for individual needle age classes averaged for all GEOMON sites are shown in Figure 5. Both reflectance and transmittance significantly differed among needle age classes except for some spectral intervals (Figure 5). On one hand, reflectance did not show significant differences among NACs across two broader spectral intervals: 1138-1354 nm and 1679-1737 $\mathrm{nm}$. On the other hand, three narrow spectral bands were equal in needle transmittance (450-487 nm, 669-683 nm, and 1888-2000 nm). Both reflectance and transmittance decreased with needle age in the green part of the visible (VIS) spectrum and similarly in the near infrared (NIR) spectral interval (800-1000 nm). For transmittance, the age-dependent differences in NIR were more apparent and pronounced in the shortwave infrared (SWIR) wavelengths. Needle-age effect on reflectance and transmittance were consistent across all studied GEOMON catchments (see Supplementary Figure S1 for details).
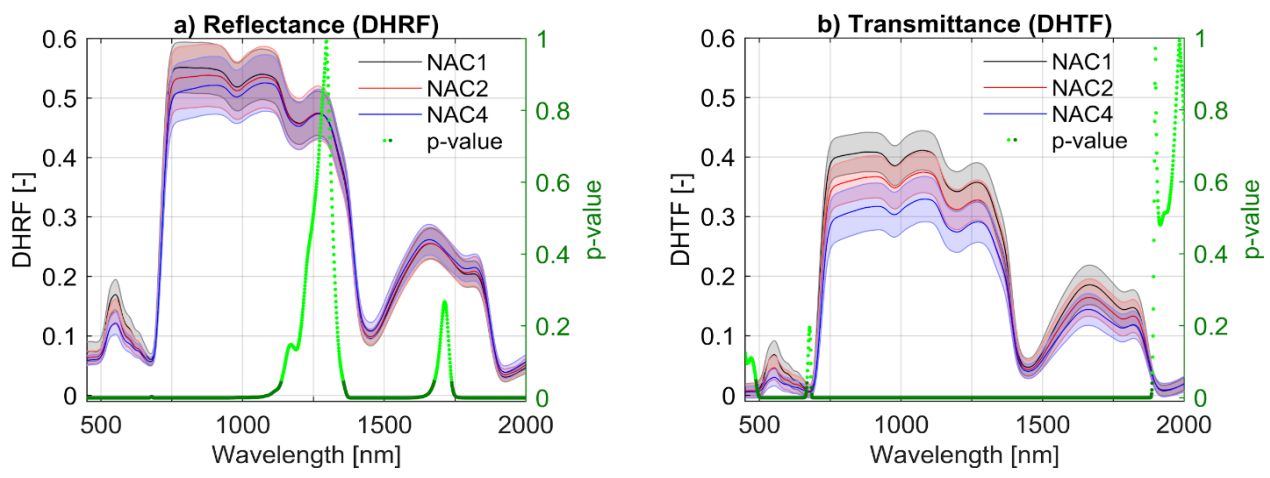

Figure 5. Needle optical properties averaged for ten GEOMON sites for current (NAC1), previousyear (NAC2) and older (NAC4) needles (left y-axis): (a) Directional-Hemispherical Reflectance Factor (DHRF); (b) directional-Hemispherical Transmittance Factor (DHTF). Solid line-average for all trees; shaded area—standard deviation; $n=123$ per needle age class. Differences among needle age classes were tested by linear mixed-effect model. $p$-values (right y-axis) indicate significant ( $\alpha=0.05$; dark green) and not significant (light green) differences between needle age classes for each wavelength.

\subsection{Needle Optical Properties-Age and Site Effects}

PCA of both reflectance and transmittance spectra showed a separation trend among needle age classes (Figure 6a,c), highlighting the difference between NAC1 and NAC4. In the case of DHRF, the separation of needle spectra due to needle age was weaker than for DHTF. The stronger separation trend among needle age in DHTF confirmed the results of the ANOVA, showing only minor spectral intervals without significant differences among needle age classes (Figure 5b). The first two components PC1 and PC2 accounted for 94 and $95 \%$ of overall variation in DHRF and DHTF, respectively. In contrast to needle age, the effect of the catchment on needle spectra separation was almost negligible (Figure 6b,d). 

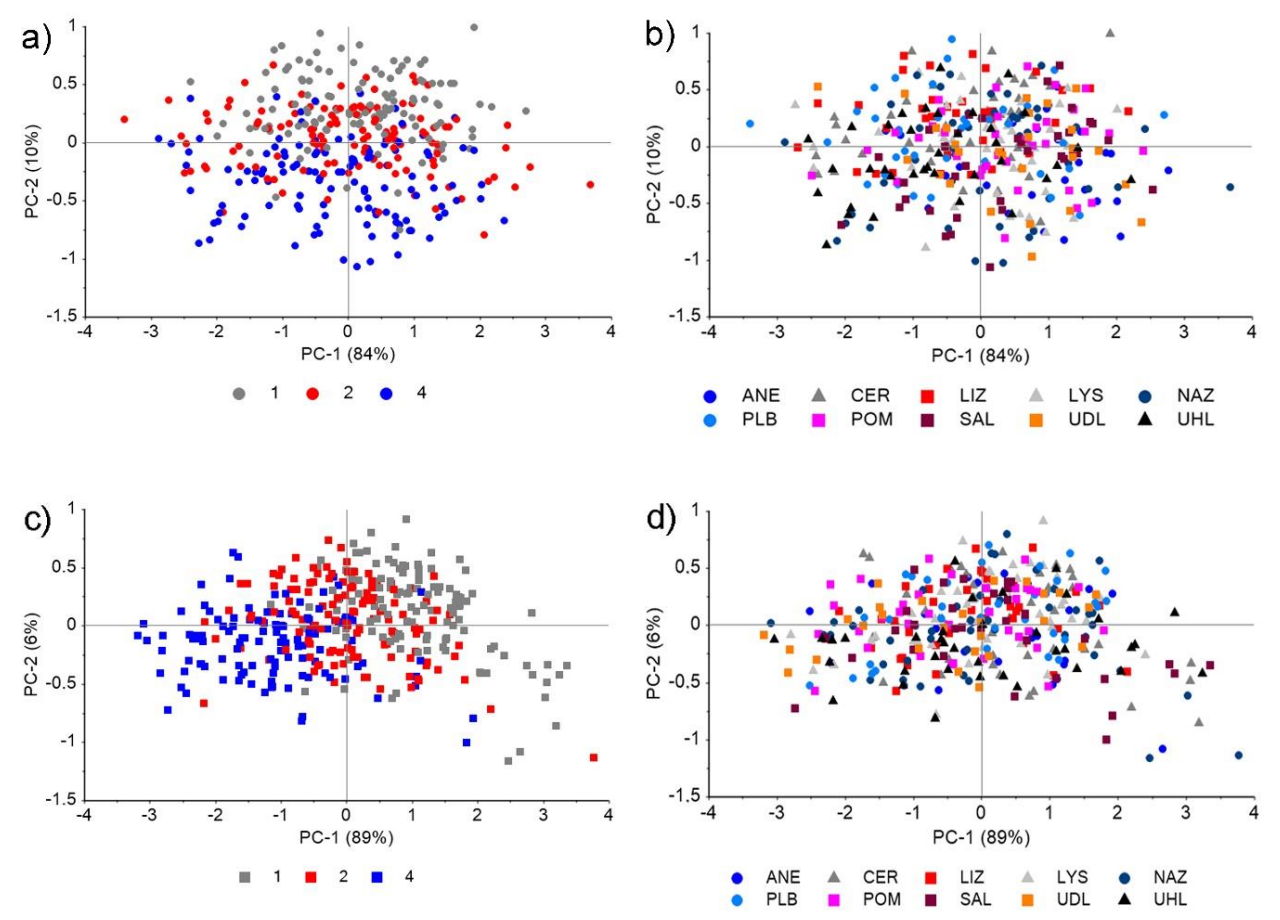

Figure 6. Score plots for principal component analysis (PCA) applied on needle optical properties. Score plot based on reflectance (DHRF) showing separation according to (a) needle age classes and (b) catchments; score plot based on transmittance (DHTF) showing separation according to (c) needle age classes and (d) catchments.

\subsection{Needle Traits PLSR Modeling-NACs Effect}

Results of cross-validation of PLSR models for selected needle traits are presented in Table 2. Models always performed better if all needle age classes were included: they showed higher coefficient of determination $\left(R^{2}\right)$, lower root mean square error (RMSE) in absolute values of given trait and lower RMSE expressed as a percentage of the training dataset range (RMSE\%), and higher residual prediction deviation (RPD) than models for individual needle age classes. The model for needle specific mass (LMA) showed the highest predictive power $\left(\mathrm{R}^{2}=0.79, \mathrm{RMSE} \% 9 \%\right.$ and RPD 2.18). The second-best predicted needle traits were soluble phenolics content $\left(\mathrm{R}^{2}=0.73, \mathrm{RMSE} \% 11 \%\right.$ and $\left.\mathrm{RPD} 1.93\right)$, total carotenoid content $\left(\mathrm{R}^{2}=0.72, \mathrm{RMSE} \% 11 \%\right.$ and $\left.\mathrm{RPD} 1.91\right)$ and chlorophyll content $\left(\mathrm{R}^{2}=0.71, \mathrm{RMSE} \% 11 \%\right.$ and RPD 1.86). The model for water content showed acceptable results $\left(\mathrm{R}^{2}=0.60, \mathrm{RMSE} \% 11 \%\right.$ and $\left.\mathrm{RPD} 1.58\right)$, but the models for lignin, chlorophyll to carotenoids ratio (Car:Cab), cellulose, nitrogen, and $\mathrm{C}: \mathrm{N}$ ratio were rather unsuccessful $\left(R^{2}=0.38 ; 0.31 ; 0.15 ; 0.23\right.$ and 0.23 , respectively).

Figure 7 shows validation of the best performing PLSR models for individual needle age classes (Figure $7 \mathrm{a}, \mathrm{c}, \mathrm{e}, \mathrm{g}$ ) and all NACs pooled together (Figure $7 \mathrm{~b}, \mathrm{~d}, \mathrm{f}, \mathrm{h}$ ). LMA was predicted very well using NAC2 and NAC1 reflectance with model parameters close to the model including all NACs. In the case of phenolic compound models, younger needles (NAC1 and NAC2) had better performance in comparison to NAC4. The model for chlorophyll content showed the best parameters ( ${ }^{2}$, RMSE, RMSE\% and RPD) for NAC1 in comparison to older needles, NAC2 and NAC4. For water content, the NAC1 model showed the best prediction power and, in some parameters ( $R^{2}$ and RPD), even outperformed the model based on all NACs together. Carotenoids showed the best performing model for NAC4 (regarding $\mathrm{R}^{2}, \mathrm{RMSE} \%$ and RPD) in comparison to NAC1 and NAC2. 


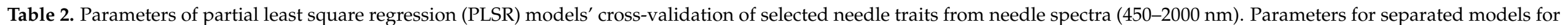

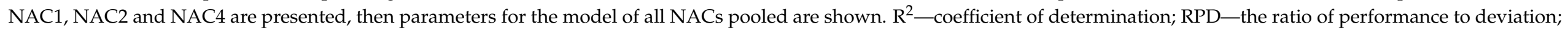

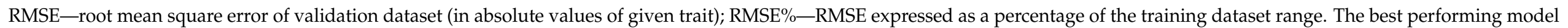
according to the highest $\mathrm{R}^{2}$ is highlighted in bold.

\begin{tabular}{|c|c|c|c|c|c|c|c|c|c|c|c|c|c|c|c|c|}
\hline \multirow[b]{2}{*}{$\begin{array}{c}\text { Needle } \\
\text { Trait }\end{array}$} & \multicolumn{4}{|c|}{ NAC 1} & \multicolumn{4}{|c|}{ NAC 2} & \multicolumn{4}{|c|}{ NAC 4} & \multicolumn{4}{|c|}{ Pooled NACs } \\
\hline & $\mathbf{R}^{2}$ & RPD & RMSEP & RMSE\% & $\mathbf{R}^{2}$ & RPD & RMSEP & RMSE\% & $\mathbf{R}^{2}$ & RPD & RMSEP & RMSE\% & $\mathbf{R}^{2}$ & RPD & RMSEP & RMSE\% \\
\hline $\begin{array}{c}\text { Chlorophyll } \\
a+b\end{array}$ & 0.44 & 1.34 & 5.31 & $15 \%$ & 0.39 & 1.26 & 7.25 & $16 \%$ & 0.43 & 1.33 & 10.44 & $16 \%$ & 0.71 & 1.86 & 8.38 & $11 \%$ \\
\hline Carotenoids & 0.45 & 1.33 & 0.62 & $14 \%$ & 0.37 & 1.26 & 0.83 & $16 \%$ & 0.52 & 1.44 & 1.10 & $14 \%$ & 0.72 & 1.91 & 0.83 & $11 \%$ \\
\hline $\begin{array}{l}\text { Car:Cab } \\
\text { ratio }\end{array}$ & 0.29 & 1.19 & 0.0100 & $17 \%$ & 0.26 & 1.33 & 0.0070 & $15 \%$ & 0.38 & 1.27 & 0.0070 & $13 \%$ & 0.31 & 1.17 & 0.0090 & $15 \%$ \\
\hline Water & 0.61 & 1.61 & 2.02 & $13 \%$ & 0.56 & 1.51 & 2.18 & $13 \%$ & 0.53 & 1.47 & 2.00 & $12 \%$ & 0.60 & 1.58 & 2.01 & $11 \%$ \\
\hline Phenolics & 0.45 & 1.34 & 0.55 & $14 \%$ & 0.53 & 1.49 & 0.71 & $12 \%$ & 0.31 & 1.21 & 0.81 & $15 \%$ & 0.73 & 1.93 & 0.82 & $11 \%$ \\
\hline Lignin & 0.37 & 1.25 & 0.059 & $15 \%$ & 0.40 & 1.28 & 0.051 & $16 \%$ & 0.28 & 1.18 & 0.049 & $14 \%$ & 0.38 & 1.27 & 0.052 & $13 \%$ \\
\hline Cellulose & 0.18 & 1.10 & 0.501 & $13 \%$ & 0.11 & 1.06 & 0.645 & $15 \%$ & 0.13 & 1.06 & 0.462 & $13 \%$ & 0.15 & 1.08 & 0.539 & $15 \%$ \\
\hline $\mathrm{N}$ & 0.31 & 1.19 & 0.119 & $18 \%$ & 0.39 & 1.28 & 0.115 & $16 \%$ & 0.15 & 1.08 & 0.134 & $16 \%$ & 0.23 & 1.14 & 0.131 & $16 \%$ \\
\hline
\end{tabular}



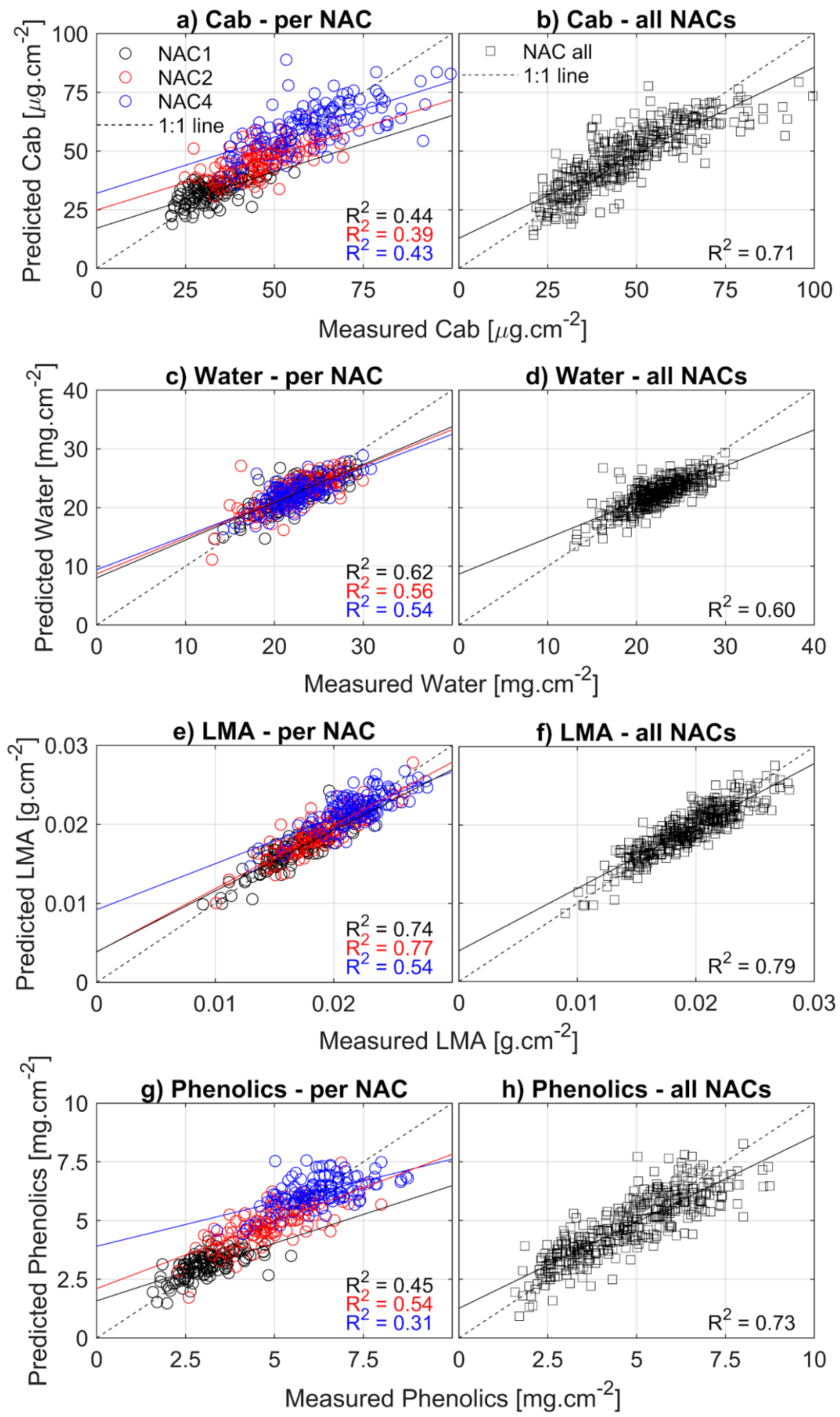

Figure 7. PLSR model validation (Cross-validation, leave-one-out) for selected needle traits. Chlorophyll $\mathrm{a}+\mathrm{b}$ content $(\mathrm{Cab})$ for $(\mathbf{a})$ individual needle age classes and (b) all NACs together; water content for (c) individual needle age classes and (d) all NACs together. Leaf mass per area (LMA) for (e) individual needle age classes (NAC) and (f) all NACs together; phenolics content for (g) individual needle age classes and (h) all NACs together. Individual needle age classes are shown in colors: NAC 1 in black; NAC 2 in red; NAC 4 in blue. Coefficients of determination $\left(\mathrm{R}^{2}\right)$ are shown for each model. 
Several needle traits such as chlorophyll or water content have more specific absorption features than others (e.g., LMA). We used the PLS regression coefficients in the spectral region $450-2000 \mathrm{~nm}$ to better explain model performance by highlighting the wavelengths contributing most to the model (Figure 8). A nearly identical pattern in the PLS regression coefficients was found for chlorophyll and carotenoid content (Figure 8a). Significant model contributions were found in the green region (negative coefficients with a peak around $535-545 \mathrm{~nm}$ ), the red region (positive coefficients between 620 and $700 \mathrm{~nm}$ with a peak around $690 \mathrm{~nm}$ ), the red-edge region (negative coefficients with a peak around 725 $\mathrm{nm}$ ) and two more regions in SWIR (positive coefficients with a peak around $1485 \mathrm{~nm}$ and negative coefficients with a peak around $1713 \mathrm{~nm}$ ). Significant model contribution of the red region is attributed to chlorophyll absorption maxima [30]. In accordance with other studies [30,72], the other sharp negative peak in regression coefficients for chlorophyll model was found in the red edge region $(725 \mathrm{~nm})$. Other significant wavelengths were detected by the PLSR coefficients besides the SWIR peak at $1485 \mathrm{~nm}$. These were located at 945,1080 , and $1930 \mathrm{~nm}$ and are related to the water content absorptions [29], showing also the intercorrelation between these two biophysical traits. Surprisingly, the absorption placed at very $1713 \mathrm{~nm}$ was found to be very important for modeling the chlorophyll content. This absorption correlates with leaf dry matter and has been used for estimations of lignin content $[29,73,74]$. For modeling needle water content (Figure 8b), the two most pronounced negative peaks in PLS regression coefficients were identified in red edge $(734 \mathrm{~nm})$ and SWIR $(1380 \mathrm{~nm})$ wavelengths, which are the water diagnostic absorption features [29]. Additionally, another important spectral region with positive coefficients was placed between 1040 and $1140 \mathrm{~nm}$. Furthermore, contributions from spectral regions around 1280, 1480 and $1900 \mathrm{~nm}$ were found and the weaker correlation between water content and the absorption placed at $1713 \mathrm{~nm}$, related to lignin, was also identified. LMA (Figure $8 b$ ) shows the highest correlation with the red region with a peak placed at 626 $\mathrm{nm}$, and the red edge region with the maxima placed at $742 \mathrm{~nm}$. Furthermore, we could observe significant contributions of wavelengths around 1100, 1300 and $1490 \mathrm{~nm}$, typically associated with water absorption. The LMA also showed a significant correlation with the $1713 \mathrm{~nm}$ lignin absorption feature.



Figure 8. PLS regression coefficients weights for models (pooled NACs) of selected needle traits in spectral region 450-2000 nm. (a) Cab-chlorophyll a+b content; Car-total carotenoids content. (b) Needle water content (area based), leaf mass per area. (c) Phenolics and lignin content. Ranges of the regression coefficients were normalized between -1 and 1 .

For phenolic and lignin content (Figure 8c), we found the same patterns of regression coefficients previously described for the biophysical traits above. When we compare the wavelength position and how pronounced the peaks are, we can see that lignin has the stronger correlation with its diagnostic absorption at $1713 \mathrm{~nm}$ and correlated also with the red edge peak placed at $730 \mathrm{~nm}$, while phenolics show stronger correlation with the low reflectance-absorption placed at $540 \mathrm{~nm}$ and the red edge peak shifted to longer 
wavelengths $(750 \mathrm{~nm})$. The correlation with the absorption at $1713 \mathrm{~nm}$ is weaker when compared to lignin.

\section{Discussion}

\subsection{Needle Biophysical Traits-Age Effects}

First, we discuss the effect of needle aging on their biophysical traits. As expected, most of the studied traits showed a significant age-dependence: LMA, photosynthetic pigments and phenolic compound contents gradually increased from current to older needles (Figures 2 and 3a). Similarly, the ratio of total carotenoids to chlorophylls increased in older needles (NAC4), corresponding with importance of accumulation of protective carotenoids [75]. However, the differences between NAC1 and NAC2 were not as profound and, for many sites, the Car:Cab ratio in NAC2 was lower than for NAC1. The accumulation of photosynthetic pigments with needle age appears to be a general phenomenon in conifers, as it was shown for Norway spruce (e.g., [76]) and other species, e.g., Pinus pinaster [54]. Accumulation of photosynthetic pigments in older needles may be important for maintenance of high photochemical efficiency in darker microenvironments, as shown in Abies alba [40]. Nitrogen needle content decreased from current to older needles (Figure $3 \mathrm{e}$ ) in most studied catchments. This is probably due to $\mathrm{N}$ recycling from older to young foliage [77-79] together with the dilution effect of accumulating dry matter (increase in LMA, Figure 3a) and also the C:N ratio increase in the majority of the studied catchments (Figure 3f). Two catchments where the $\mathrm{N}$ and $\mathrm{C}: \mathrm{N}$ ratio did not follow the same pattern as observed at the other catchments were PLB and UHL. PLB is the only site with Mgrich serpentinite bedrock and UHL was one of two completely deforested catchments in the 1990s due to heavy acid deposition loads. Both PLB and UHL belong to the most N saturated catchments [16], which was manifested by high dissolved and gaseous $\mathrm{N}$ losses. Therefore, at PLB and UHL catchments, tree growth is not N-limited and the nitrogen translocation from older to young needles is not necessary.

Higher contents of soluble phenolic compounds in older Norway spruce needles in comparison to the current ones were described before $[38,47,76,80]$. The enhanced accumulation of phenolics, either soluble phenolics or lignin in needles, is considered a non-specific stress indicator [81]. This phenomenon is probably connected with defense mechanisms against fungal and herbivore attacks [38].

Structural compounds (cellulose and lignin) and water content were independent of needle age in the present study, although some age-dependent trends were described in the literature even for these traits in various conifer species. Lignin, cellulose, and C content decreased with needle age in Picea abies $\times$ obovata from northern taiga [82]. The similar cellulose content decrease from current to older needles was observed in Norway spruce growing on a base cation-poor crystalline bedrock, with LYS from the current study being one of the forest stands in focus [83]. Probably due to great variance in cellulose needle content (Figure $3 b$ ), there was no general trend related to needle age, which is consistent also with [83]. Needle water content trends varied among the studied sites and the age effect was not statistically significant (Figure 3d). Some catchments, however, showed a trend of lower water content in older needles (LIZ, LYS, NAZ, PLB), which is in accordance with the decrease in water content for older needles observed for Abies alba [40] and Pinus contorta [84].

\subsection{Needle Traits and Soil Properties-Site Effects}

The ten GEOMON catchments significantly differed from their soil properties (Supplementary Table S1), particularly by exchangeable acidity, and base cations concentrations, and less from their needle biophysical traits. Despite the sulphur deposition-the main acidifying factor, which generally decreased at the GEOMON catchments between 1994 and 2014 by ca $70-80 \%$ [16] - , the differences among the catchments given by the parent bedrock or forest management became more apparent. On one hand, high base cations content, higher base saturation, and low exchangeable acidity in NAZ and PLB catchments 
(Figure 4), were observed in FH horizon, which corresponded to Mg-rich serpentinite bedrock (PLB, [85] and Ca-Mg rich amphibolite bedrock (NAZ [20]). On the other hand, UHL and LYS exhibited high exchangeable acidity, and low base cations due to Ca-poor granite bedrock [86]. The UDL catchment was seriously affected by air-pollution, which caused forest decline in the past, and forest management interventions, particularly the application of dolomitic limestone between 1980 and 2007 [87], were most pronounced there. As a result, UDL catchment, naturally underlined by a Ca poor bedrock (orthogneiss) exhibited relatively low exchangeable acidity and high base saturation in the forest floor. This was further accompanied by high $\mathrm{N}$ soil concentration and low soil C:N ratio.

Some needle traits, however, also contributed to among-site variability in PC1. These were chlorophyll and carotenoid contents mainly in young needles (NAC2 and NAC1). Surprisingly, photosynthetic pigment content correlated negatively with $\mathrm{Mg}$ and Ca soil contents and positively with total soil potassium, phosphorus, and exchangeable acidity. These relationships almost disappeared for older needles, where $\mathrm{P}$ and $\mathrm{K}$ resorption to younger tissues may be the cause [41]. Regardless of the needle age, LMA, and nonpigment compounds (lignin, phenolics, water and cellulose), showed less dependence on soil properties, only being influential in PC2. In the PCA models for current- and previous-year needles, soluble phenolic needle content negatively correlated with $\mathrm{N}$ needle content, which is consistent with the finding that $\mathrm{N}$ fertilization leads to a decrease in various carbon-based secondary metabolites in current Norway spruce needles, such as flavonoids and tannins [38]. There was also an apparent negative correlation between needle $\mathrm{N}$ content and organic soil C: $\mathrm{N}$ ratio, which diminished in older needles. A similar relationship was observed by Aitkenhead-Peterson et al. [83] for C:N in Norway spruce forest floors. This further highlights the employment of foliar $\mathrm{N}$ as a good predictor of site trophic status.

To conclude, the larger part of variation among the ten studied sites can be described by intrinsic soil properties. Needle photosynthetic pigments (chlorophyll and carotenoids) and $\mathrm{N}$ content are correlated with soil properties, particularly in NAC1 and NAC2 needles. Needle structural traits (LMA, lignin, cellulose) and water are rather independent of soil properties.

\subsection{Variation in Needle Optical Properties-Age and Site Effects}

Needle optical properties varied according to needle age consistently in all ten studied sites (Figure 5 and Supplementary Figure S1). Reflectance in the VIS region, particularly in green wavelengths, decreased with needle age, which corresponds well with chlorophyll accumulation. In NIR between 800 and $1000 \mathrm{~nm}$, reflectance decreased with needle age, but in the shortwave infrared wavelengths there was almost no difference among age classes (Figure 4). Transmittance in the VIS region behaved the same as reflectance, showing a decrease with needle age. In NIR and SWIR, transmittance exhibited significant differences among needle age classes with the highest values for the NAC1. The more pronounced agedependence in transmittance in the NIR and SWIR ranges (in comparison to reflectance) resulted in considerably better needle age class spectra separation by PCA (Figure 6a,c). The age effect on needle optical properties was similar, as shown by Hovi et al. [88] for nine boreal coniferous species. Although Hovi et al. [88] focused only on NAC1 and NAC2, we showed that the optical properties changed similarly with further needle aging. The decreasing transmittance in NIR and SWIR wavelengths could be attributed to cell expansion and accumulation of structural compounds expressed as increasing LMA (Figure 3a), both of which result in the reduction in intercellular spaces in the mesophyll, as shown by Rock et al. [89], in Picea rubens and Tsuga canadensis. Our results, similar to those of [88], clearly show that the age-related differences in needle optical properties are wavelength dependent (Figure 4), which is important to be aware of if dealing with simple ratio or normalized difference vegetation indices. A study by Dengel [90] detected stress by various vegetation indices along an altitudinal gradient in subarctic Pinus sylvestris, and some of the routinely used indices (NDVI, chlNDVI and REP) were equal for the five 
youngest needle age classes. Needle age-effect on the optical properties at the leaf level has been covered by several studies (e.g., [88]) to date. However, much less attention has been paid to upscaling this phenomenon to the canopy level. A recent study by $\mathrm{Wu}$ et al. [91] conducted on Chinese fir showed that needle-age dependent seasonal changes in leaf optical properties resulted in canopy NIR reflectance trends across the season. Thus, the needle age effect should be considered with seasonal effects for better interpretation of satellite remote sensing data.

We discussed considerable variation in needle optical properties given by the needle age, which was consistent across all studied catchments (Supplementary Figure S1). Regarding differences in optical properties among individual GEOMON sites, PCA did not reveal any trend to catchment separation and sample scores were homogeneously scattered (Figure $6 \mathrm{~b}, \mathrm{~d}$ ). Lately, there have been efforts to use plant spectra as surrogates for important belowground processes [31,32] and canopy spectra appeared to correlate well with soil nitrogen and activity of selected microbial enzymes [32]. Although soil conditions at GEOMON catchments represent substantial gradient in soil properties, we were not able to find any site-related pattern in needle reflectance and transmittance. Recently, significant improvement from acidification was observed in the GEOMON headwater catchments network [16], which could result in the absence of differences in optical properties of studied needle age classes. In extreme cases, like post-mining sites with substrates rich in $\mathrm{S}$ and trace metal (As, Cu, Zn), the Pinus sylvestris needle spectral and biophysical properties can reflect the soil properties and separate the sites with different soil conditions [92]. However, in the present study, we did not focus directly on relationships or modeling of soil traits from needle spectra, which will be a subsequent step in exploiting a rich dataset from the GEOMON network.

In general, the measurement of optical properties of narrow, irregular leaves of conifers is challenging as the narrow needles do not fully cover the sample port in integrating spheres and the most common practice is to fix needles in a special carrier with some gaps between them [57,60,93-95]. In particular, needle transmittance measurements are influenced by the gap effect (additional signal transmitted through gaps, signal multiple scattering at the edge of needles and light interaction with a carrier), which often results in erroneous negative transmittance values mainly in the VIS range (as shown, e.g., by Olascoaga et al. [60] for Picea abies and Pinus sylvestris, and as was also the case in this study). Therefore, results based on spectral transmittance should be interpreted with care and transmittance was not used for trait modeling. Nevertheless, the PCA analysis pointed to larger spectral variation within a single tree due to needle age effect than between stands growing in different environmental conditions.

\subsection{Needle Traits PLSR Modeling-NACs Effect}

We selected PLSR as the target regression method for modeling Norway spruce needle biophysical traits for following reasons: as a nonparametric approach, PLSR takes advantage of model training with the full spectrum of information, is designed to deal with spectral data multicollinearity, and includes a dimensionality reduction step [67,96]. Among the multitude of approaches in biophysical parameter retrieval, PLSR has recently been successfully applied in plenty of vegetation studies both on leaf level spectral data, e.g., [92,97-99], canopy-level imaging spectroscopy, e.g., [72], and other studies mentioned in the review by the authors of [96].

The best performing PLSR models based on mixed NACs (Table 2, Figure 7) exhibited slightly lower $\mathrm{R}^{2}$ than other recent studies: LMA $\mathrm{R}^{2}=0.79 \mathrm{LMA}$ (present study) compared to 0.90 in [97]; phenolics $R^{2}=0.73$ (present study) compared to 0.83 in [98]; chlorophyll $R^{2}=$ 0.71 (present study) compared to 0.89 and 0.94 in $[92,100]$, respectively; and water $R^{2}=0.60$ (present study) compared to 0.89 in [97]. In some cases, a lower model performance in the present study probably resulted from the needle-like leaf form of Norway spruce, which may cause difficulties in measuring optical properties at the needle level, as discussed above. The cited studies for model performance comparison $[97,98]$ were performed on 
broad leaved species—annual crops and poplar cuttings, and Asian broadleaved forest tree species, respectively.

Our results clearly show that needle age has a significant effect on PLSR models' performance (Table 2). For almost all studied traits, the models based on mixed NACs performed the best regarding $\mathrm{R}^{2}$ and RPD. This result is to be expected for needle traits, which are age-dependent themselves, such as chlorophyll, carotenoid and phenolic content and LMA, due to the extension of the training dataset range. However, the mixed NACs model performed the best also for lignin, a trait without significant age dependence. This finding supports using several needle age classes for functional traits' retrieval from the hyperspectral data.

If we focus on models for individual NACs, the results were not consistent-for chlorophyll $\mathrm{a}+\mathrm{b}$ and water, the best performing models resulted for NAC1. Considering chlorophyll and water as the most usually monitored traits from the optical signal, it may not bring a serious bias if only current year needles are sampled for model calibration, as in case of study by [101] and many others. On the contrary, LMA, soluble phenolics and lignin showed the best performing models for NAC2 and carotenoids and Car:Cab ratio even for NAC4. The hyperspectral data contain information about a broad range of leaf traits connected to plant physiological performance [102], carbon-nitrogen status and source-sink balance [97]. Therefore, the best way to cover as many traits as possible is to use mixed age classes data. In some chemometric studies dealing with evergreen conifers, the biochemical traits were modeled by PLSR from spectra measured on dried and homogenized needles and the models were always trained on mixed age classes $[99,103]$. Similarly, Schlerf et al. [104] included NAC1 and NAC3 for chlorophyll and nitrogen retrieval in Norway spruce, both at the leaf and canopy level. However, neither of the studies evaluated the model performance for the NACs separately. One of the scarce studies focused on needle functional traits relation to its optical properties for individual age classes was conducted by Kováč et al. [51]. The green reflectance continuum removal-based optical index was correlated to the xanthophyll de-epoxidation state of Norway spruce foliage. The relationships for various NACs were compared and the linear regression between optical index and the xanthophyll de-epoxidation state showed higher $\mathrm{R}^{2}$ for NAC2 (0.63) than for NAC1 and NAC2 mixed (0.61). However, needles from different vertical canopy positions were examined, which could influence such dynamic leaf traits, such as the xanthophyll de-epoxidation state. The recent study by Wu et al. [91] strongly supports our idea of always using more needle age classes for taking ground truth for evergreen conifers with a long lifespan foliage. The authors went even further and showed the differences in optical properties seasonal dynamics for new needles (NAC1) and mature needles (NAC2 and older), which had a serious impact on NIR canopy reflectance of evergreen coniferous forests [91].

To sum up, we have analyzed the variability in needle traits induced by needle age only at the top level of the tree crown. However, we are convinced that if we also included needles across the vertical crown profile, we would probably find even more pronounced differences due to needle acclimation to shade conditions [36,44,45]. Understanding of foliage traits' heterogeneity within a tree crown can help to better scale and interpret remotely sensed spectral information by upscaling (for instance, via 3D radiative transfer models).

\section{Conclusions}

This study provided deeper insight into the variability of needle biophysical traits and optical properties of the most common productive tree species in Central Europe-Norway spruce. Our database of needle traits was compiled from 123 spruce trees growing in different environmental conditions and was further complemented by information about sites' soil properties. We confirmed the age-dependence of most studied needle biophysical traits: pigments (chlorophyll $\mathrm{a}+\mathrm{b}$ and carotenoid contents), leaf mass per area, water and phenolics content. We found out that variation in needle optical traits was mainly driven by 
the presence of different needle age classes within a single tree crown rather than different catchments' environmental conditions. Needle reflectance in the VIS and NIR regions and transmittance in the VIS, NIR and SWIR regions decreased with increasing needle age. This also influenced the accuracy of PLSR prediction models of needle traits, which varied among the needle age classes. Traits that could be modeled with moderate accuracy were needle pigments (chlorophyll $\mathrm{a}+\mathrm{b}$ and carotenoid contents), leaf mass per area, water and phenolics content. Traits with low prediction accuracies were lignin, cellulose, and nitrogen content. PLSR models always performed better if all needle age classes were included in comparison to single age-class based models, which applied also to needle-age independent traits (water and lignin). Variability among ten catchments could be largely attributed to different soil properties (mainly to exchangeable acidity, total phosphorus content, $\mathrm{pH}$, base saturation, and content of base cations that formed the PC1 axis, explaining about $27 \%$ of the total variability) rather than to differences in needle biophysical traits (which formed the PC2 axis, explaining about $18 \%$ of the total variability). Due to the significant age-dependence of many needle traits, and also the effect of needle-age on PLSR models performance, we recommend including not only the current but also older needle traits as ground truth for Norway spruce, and probably for other conifers bearing several needle age classes.

Supplementary Materials: The following are available online at https:/ /www.mdpi.com/2072-429 2/13/3/391/s1, Supplementary Table S1: Selected properties of FH horizon used in PCA analysis, Supplementary Figure S1: Needle optical properties separately for ten GEOMON sites for current (NAC1), previous-year (NAC2) and older (NAC4) needles. Supplementary Figure S1: Weather conditions for the period of needle sampling at GEOMON catchments.

Author Contributions: Conceptualization, Z.L., V.K.-S., L.H. and F.O.; formal analysis, Z.L., V.K.-S., E.N., R.J. and M.Š.; investigation, Z.L. and E.N.; resources, F.O.; data curation, L.H., E.N., Z.L. and F.O.; writing —original draft preparation, Z.L., L.H., V.K.-S., E.N., F.O. and J.A.; writing-review and editing, Z.L., L.H., V.K.-S. and J.A.; visualization, L.H., M.Š. and Z.L.; supervision, Z.L.; project administration, L.H.; funding acquisition, L.H. All authors have read and agreed to the published version of the manuscript.

Funding: This research was funded by The Czech Science Foundation, grant number 17-05743S and by the Ministry of Education, Youth and Sports of Czech Republic within the CzeCOS program.

Data Availability Statement: The data presented in this study are available on reasonable request from the corresponding author.

Acknowledgments: We would like to thank students from Charles University who helped with needle sampling in 2017, Drahomíra Bartáková for technical help with biochemical analyses, and Miroslav Barták for biochemical analyses and help with graphics editing. We thank our nativespeaker colleague Lena Hunt for the English proof-reading. We thank Pavel Krám for reading and commenting on the manuscript before submission. Finally, we thank the three anonymous reviewers whose comments have improved the manuscript.

Conflicts of Interest: The authors declare no conflict of interest, and the funders had no role in the design of the study; in the collection, analyses, or interpretation of data; in the writing of the manuscript, or in the decision to publish the results.

\section{References}

1. McGloin, R.; Šigut, L.; Fischer, M.; Foltýnová, L.; Chawla, S.; Trnka, M.; Pavelka, M.; Marek, M.V. Available Energy Partitioning During Drought at Two Norway Spruce Forests and a European Beech Forest in Central Europe. J. Geophys. Res. Atmos. 2019, 124, 3726-3742. [CrossRef]

2. Altman, J.; Fibich, P.; Santruckova, H.; Dolezal, J.; Stepanek, P.; Kopacek, J.; Hunova, I.; Oulehle, F.; Tumajer, J.; Cienciala, E. Environmental factors exert strong control over the climate-growth relationships of Picea Abies in Central Europe. Sci. Total Environ. 2017, 609, 506-516. [CrossRef]

3. Sitková, Z.; Sitko, R.; Vejpustková, M.; Pajtík, J.; Šrámek, V. Intra- and Interannual Variability in Diameter Increment of Fagus Sylvatica L. and Picea Abies L. Karst. in Relation to Weather Variables. Cent. Eur. For. J. 2018, 64, 223-237. [CrossRef] 
4. Tumajer, J.; Altman, J.; Štěpánek, P.; Treml, V.; Doležal, J.; Cienciala, E. Increasing moisture limitation of Norway spruce in Central Europe revealed by forward modelling of tree growth in tree-ring network. Agric. For. Meteorol. 2017, 247, 56-64. [CrossRef]

5. Mezei, P.; Jakuš, R.; Pennerstorfer, J.; Havašová, M.; Škvarenina, J.; Ferenčík, J.; Slivinský, J.; Bičárová, S.; Bilčík, D.; Blaženec, M.; et al. Storms, temperature maxima and the Eurasian spruce bark beetle Ips typographus-An infernal trio in Norway spruce forests of the Central European High Tatra Mountains. Agric. For. Meteorol. 2017, 242, 85-95. [CrossRef]

6. Oulehle, F.; Wright, R.F.; Svoboda, M.; Bače, R.; Matějka, K.; Kaňa, J.; Hruška, J.; Couture, R.-M.; Kopáček, J. Effects of Bark Beetle Disturbance on Soil Nutrient Retention and Lake Chemistry in Glacial Catchment. Ecosystems 2019, 22, 725-741. [CrossRef]

7. Potterf, M.; Nikolov, C.; Kočická, E.; Ferenčík, J.; Mezei, P.; Jakuš, R. Landscape-level spread of beetle infestations from windthrown- and beetle-killed trees in the non-intervention zone of the Tatra National Park, Slovakia (Central Europe). For. Ecol. Manag. 2019, 432, 489-500. [CrossRef]

8. Holuša, J.; Lubojacký, J.; Curn, V.; Tonka, T.; Lukášová, K.; Horák, J. Combined effects of drought stress and Armillaria infection on tree mortality in Norway spruce plantations. For. Ecol. Manag. 2018, 427, 434-445. [CrossRef]

9. Knížek, M. (Ed.) Škodliví Činitelé v Lesích Česka 2018/2019. Historie a Současnost Kưrovcových Kalamitve Středni Evropě; Zpravodaj Ochrany Lesa; Forestry and Game Management Research Institute: Jíloviště, Czechia, 2019; ISBN 978-80-7417-186-4. (In Czech)

10. Campbell, P.K.E.; Rock, B.N.; Martín, M.E.; Neefus, C.D.; Irons, J.R.; Middleton, E.M.; Albrechtová, J. Detection of initial damage in Norway spruce canopies using hyperspectral airborne data. Int. J. Sens. 2004, 25, 5557-5583. [CrossRef]

11. Kupková, L.; Potůčková, M.; Lhotáková, Z.; Albrechtová, J. Forest cover and disturbance changes, and their driving forces: A case study in the Ore Mountains, Czechia, heavily affected by anthropogenic acidic pollution in the second half of the 20th century. Environ. Res. Lett. 2018, 13, 095008. [CrossRef]

12. Putalová, T.; Vacek, Z.; Vacek, S.; Štefančík, I.; Bulušek, D.; Král, J. Tree-Ring Widths as an Indicator of Air Pollution Stress and Climate Conditions in Different Norway Spruce Forest Stands in the Krkonoše Mts. Cent. Eur. For. J. 2018, 64, 21-33. [CrossRef]

13. Fottová, D. Regional evaluation of mass element fluxes: Geomon network of small catchments. Environ. Monit. Assess. 1995, 34, 215-221. [CrossRef] [PubMed]

14. Fottová, D.; Skorepova, I. Changes in Mass Element Fluxes and their Importance for Critical Loads: Geomon Network, Czech Republic. Water Air Soil Pollut. 1998, 105, 365-376. [CrossRef]

15. Hruška, J.; Moldan, F.; Krám, P. Recovery from acidification in central Europe-observed and predicted changes of soil and streamwater chemistry in the Lysina catchment, Czech Republic. Environ. Pollut. 2002, 120, 261-274. [CrossRef]

16. Oulehle, F.; Chuman, T.; Hruška, J.; Krám, P.; McDowell, W.H.; Myška, O.; Navrátil, T.; Tesař, M. Recovery from acidification alters concentrations and fluxes of solutes from Czech catchments. Biogeochemistry 2017, 132, 251-272. [CrossRef]

17. Hruška, J.; Cudlín, P.; Krám, P. Relationships between Norway Spruce Status and Soil Water Base Cations / Aluminium in the Czech Republic. Water Air Soil Pollut. 2001, 130, 983-988. [CrossRef]

18. Růžek, M.; Myška, O.; Kučera, J.; Oulehle, F. Input-Output Budgets of Nutrients in Adjacent Norway Spruce and European Beech Monocultures Recovering from Acidification. Forests 2019, 10, 68. [CrossRef]

19. Hruška, J.; Krám, P.; McDowell, W.H.; Oulehle, F. Increased Dissolved Organic Carbon (DOC) in Central European Streamsis Driven by Reductions in Ionic Strength Rather than Climate Change or Decreasing Acidity. Environ. Sci. Technol. 2009, 43, 4320-4326. [CrossRef]

20. Krám, P.; Hruška, J.; Shanley, J.B. Streamwater chemistry in three contrasting monolithologic Czech catchments. Appl. Geochem. 2012, 27, 1854-1863. [CrossRef]

21. Novotný, J.; Navrátilová, B.; Janoutová, R.; Oulehle, F.; Homolová, L. Influence of Site-Specific Conditions on Estimation of Forest above Ground Biomass from Airborne Laser Scanning. Forests 2020, 11, 268. [CrossRef]

22. Švik, M.; Oulehle, F.; Krám, P.; Janoutová, R.; Tajovská, K.; Homolová, L. Landsat-Based Indices Reveal Consistent Recovery of Forested Stream Catchments from Acid Deposition. Remote Sens. 2020, 12, 1944. [CrossRef]

23. Huang, C.; Anderegg, W.R.L.; Asner, G.P. Remote sensing of forest die-off in the Anthropocene: From plant ecophysiology to canopy structure. Remote Sens. Environ. 2019, 231, 111233. [CrossRef]

24. Kopackova, V.; Misurec, J.; Lhotáková, Z.; Oulehle, F.; Albrechtová, J. Using multi-date high spectral resolution data to assess the physiological status of macroscopically undamaged foliage on a regional scale. Int. J. Appl. Earth Obs. Geoinf. 2014, 27, 169-186. [CrossRef]

25. Mišurec, J.; Kopačková, V.; Lhotáková, Z.; Campbell, P.; Albrechtová, J. Detection of Spatio-Temporal Changes of Norway Spruce Forest Stands in Ore Mountains Using Landsat Time Series and Airborne Hyperspectral Imagery. Remote Sens. $2016,8,92$. [CrossRef]

26. Mišurec, J.; Kopačková, V.; Lhotáková, Z.; Hanuš, J.; Weyermann, J.; Entcheva-Campbell, P.; Albrechtová, J. Utilization of Hyperspectral Image Optical Indices to Assess the Norway Spruce Forest Health Status. J. Appl. Remote Sens. 2012, 6, 063545. [CrossRef]

27. Rock, B.N.; Hoshizaki, T.; Miller, J.R. Comparison of in situ and airborne spectral measurements of the blue shift associated with forest decline. Remote Sens. Environ. 1988, 24, 109-127. [CrossRef]

28. Gates, D.M.; Keegan, H.J.; Schleter, J.C.; Weidner, V.R. Spectral Properties of Plants. Appl. Opt. 1965, 4, 11-20. [CrossRef]

29. Kokaly, R.F.; Asner, G.P.; Ollinger, S.V.; Martin, M.E.; Wessman, C.A. Characterizing canopy biochemistry from imaging spectroscopy and its application to ecosystem studies. Remote Sens. Environ. 2009, 113, S78-S91. [CrossRef] 
30. Ustin, S.L.; Gitelson, A.A.; Jacquemoud, S.; Schaepman, M.; Asner, G.P.; Gamon, J.A.; Zarco-Tejada, P. Retrieval of foliar information about plant pigment systems from high resolution spectroscopy. Remote Sens. Environ. 2009, 113, S67-S77. [CrossRef]

31. Madritch, M.; Cavender-Bares, J.; Hobbie, S.E.; Townsend, P.A. Linking Foliar Traits to Belowground Processes. In Remote Sensing of Plant Biodiversity; Springer International Publishing: Cham, Switzerland, 2020; pp. 193-217. ISBN 978-3-030-33157-3.

32. Madritch, M.D.; Kingdon, C.C.; Singh, A.; Mock, K.E.; Lindroth, R.L.; Townsend, P.A. Imaging spectroscopy links aspen genotype with below-ground processes at landscape scales. Philos. Trans. R. Soc. B Biol. Sci. 2014, 369, 20130194. [CrossRef]

33. Mzinyane, T.; Van Aardt, J.; Gebreslasie, M.T. Soil Carbon Estimation from Eucalyptus Grandis Using Canopy Spectra. South Afr. J. Geomat. 2015, 4, 548. [CrossRef]

34. Albrechtová, J.; Seidl, Z.; Aitkenhead-Peterson, J.; Lhotáková, Z.; Rock, B.N.; Alexander, J.E.; Malenovský, Z.; McDowell, W.H. Spectral analysis of coniferous foliage and possible links to soil chemistry: Are spectral chlorophyll indices related to forest floor dissolved organic C and N? Sci. Total Environ. 2008, 404, 424-432. [CrossRef] [PubMed]

35. Rautiainen, M.; Lukeš, P.; Homolová, L.; Hovi, A.; Pisek, J.; Mõttus, M. Spectral properties of coniferous forests: A review of in situ and laboratory measurements. Remote Sens. 2018, 10, 207. [CrossRef]

36. Homolová, L.; Lukeš, P.; Malenovský, Z.; Lhotáková, Z.; Kaplan, V.; Hanuš, J. Measurement methods and variability assessment of the Norway spruce total leaf area: Implications for remote sensing. Trees 2013, 27, 111-121. [CrossRef]

37. O'Neill, A.L.; Kupiec, J.A.; Curran, P.J. Biochemical and reflectance variation throughout a Sitka spruce canopy. Remote Sens. Environ. 2002, 80, 134-142. [CrossRef]

38. Nybakken, L.; Lie, M.H.; Julkunen-Tiitto, R.; Asplund, J.; Ohlson, M. Fertilization Changes Chemical Defense in Needles of Mature Norway Spruce (Picea Abies). Front. Plant Sci. 2018, 9, 9. [CrossRef]

39. Rummukainen, A.; Julkunen-Tiitto, R.; Ryyppö, A.; Kaunisto, S.; Kilpeläinen, J.; Lehto, T. Long-term effects of boron and copper on phenolics and monoterpenes in Scots pine (Pinus sylvestris L.) needles. Plant Soil 2013, 373, 485-499. [CrossRef]

40. Robakowski, P.; Bielinis, E. Needle age dependence of photosynthesis along a light gradient within an Abies alba crown. Acta Physiol. Plant. 2017, 39. [CrossRef]

41. Achat, D.L.; Pousse, N.; Nicolas, M.; Augusto, L. Nutrient remobilization in tree foliage as affected by soil nutrients and leaf life span. Ecol. Monogr. 2018, 88, 408-428. [CrossRef]

42. Aphalo, P.; Schoettle, A.; Lehto, T. Leaf life span and the mobility of "non-mobile" mineral nutrients—the case of boron in conifers. Silva Fenn. 2002, 36. [CrossRef]

43. Szymura, T.H. Concentration of elements in silver fir (Abies alba Mill.) needles as a function of needles' age. Trees 2009, 23, 211-217. [CrossRef]

44. Kubínová, Z.; Janáček, J.; Lhotáková, Z.; Šprtová, M.; Kubínová, L.; Albrechtová, J. Norway spruce needle size and cross section shape variability induced by irradiance on a macro- and microscale and CO2 concentration. Trees 2018, 32, 231-244. [CrossRef]

45. Lukeš, P.; Stenberg, P.; Rautiainen, M.; Mõttus, M.; Vanhatalo, K.M. Optical properties of leaves and needles for boreal tree species in Europe. Remote Sens. Lett. 2013, 4, 667-676. [CrossRef]

46. Deepak, M.; Keski-Saari, S.; Fauch, L.; Granlund, L.; Oksanen, E.; Keinänen, M. Leaf Canopy Layers Affect Spectral Reflectance in Silver Birch. Remote Sens. 2019, 11, 2884. [CrossRef]

47. Lhotáková, Z.; Albrechtová, J.; Malenovský, Z.; Rock, B.N.; Polák, T.; Cudlín, P. Does the azimuth orientation of Norway spruce (Picea Abies/L./Karst.) branches within sunlit crown part influence the heterogeneity of biochemical, structural and spectral characteristics of needles? Environ. Exp. Bot. 2007, 59, 283-292. [CrossRef]

48. Atherton, J.; Olascoaga, B.; Alonso, L.; Porcar-Castell, A. Spatial Variation of Leaf Optical Properties in a Boreal Forest Is Influenced by Species and Light Environment. Front. Plant Sci. 2017, 8, 309. [CrossRef]

49. de Tomás Marín, S.; Novák, M.; Klančnik, K.; Gaberščik, A. Spectral Signatures of Conifer Needles Mainly Depend on Their Physical Traits. Pol. J. Ecol. 2016, 64, 1-13. [CrossRef]

50. Hernández-Clemente, R.; Navarro-Cerrillo, R.M.; Suárez, L.; Morales, F.; Zarco-Tejada, P.J. Assessing structural effects on PRI for stress detection in conifer forests. Remote Sens. Environ. 2011, 115, 2360-2375. [CrossRef]

51. Kováč, D.; Malenovský, Z.; Urban, O.; Spunda, V.; Kalina, J.; Ač, A.; Kaplan, V.; Hanuš, J. Response of green reflectance continuum removal index to the xanthophyll de-epoxidation cycle in Norway spruce needles. J. Exp. Bot. 2013, 64, 1817-1827. [CrossRef]

52. Bernier, P.Y.; Raulier, F.; Stenberg, P.; Ung, C.-H. Importance of needle age and shoot structure on canopy net photosynthesis of balsam fir (Abies balsamea): A spatially inexplicit modeling analysis. Tree Physiol. 2001, 21, 815-830. [CrossRef]

53. Jensen, A.M.; Warren, J.M.; Hanson, P.J.; Childs, J.; Wullschleger, S.D. Needle age and season influence photosynthetic temperature response and total annual carbon uptake in mature Picea mariana trees. Ann. Bot. 2015, 116, 821-832. [CrossRef] [PubMed]

54. Warren, C.R. Why does photosynthesis decrease with needle age in Pinus pinaster? Trees 2006, 20, 157-164. [CrossRef]

55. Chuman, T.; Oulehle, F.; Zajícová, K.; Hruška, J. The Legacy of Acidic Deposition Controls Soil Organic Carbon Pools in Temperate Forests across the Czech Republic. Eur. J. Soil Sci. 2020, 1-22. [CrossRef]

56. Malenovský, Z.; Albrechtová, J.; Lhotáková, Z.; Zurita-Milla, R.; Clevers, J.G.P.W.; Schaepman, M.E.; Cudlín, P. Applicability of the PROSPECT model for Norway spruce needles. Int. J. Remote Sens. 2006, 27, 5315-5340. [CrossRef]

57. Yanez-Rausell, L.; Malenovsky, Z.; Clevers, J.G.P.W.; Schaepman, M.E. Minimizing Measurement Uncertainties of Coniferous Needle-Leaf Optical Properties. Part II: Experimental Setup and Error Analysis. IEEE J. Sel. Top. Appl. Earth Obs. Remote Sens. 2014, 7, 406-420. [CrossRef] 
58. Di Vittorio, A.V. Enhancing a leaf radiative transfer model to estimate concentrations and in vivo specific absorption coefficients of total carotenoids and chlorophylls a and b from single-needle reflectance and transmittance. Remote Sens. Environ. 2009, 113, 1948-1966. [CrossRef]

59. Mesarch, M.A.; Walter-Shea, E.A.; Asner, G.P.; Middleton, E.M.; Chan, S.S. A Revised Measurement Methodology for Conifer Needles Spectral Optical Properties: Evaluating the Influence of Gaps between Elements. Remote Sens. Environ. 1999, 68, 177-192.

60. Olascoaga, B.; Mac Arthur, A.; Atherton, J.; Porcar-Castell, A. A comparison of methods to estimate photosynthetic light absorption in leaves with contrasting morphology. Tree Physiol. 2016, 36, 368-379. [CrossRef]

61. Porra, R.; Thompson, W.; Kriedemann, P. Determination of Accurate Extinction Coefficients and Simultaneous-Equations for Assaying Chlorophyll-a and Chlorophyll-B Extracted with 4 Different Solvents-Verification of the Concentration. Biochim. Biophys. Acta 1989, 975, 384-394. [CrossRef]

62. Wellburn, A.R. The Spectral Determination of Chlorophylls a and b, as well as Total Carotenoids, Using Various Solvents with Spectrophotometers of Different Resolution. J. Plant Physiol. 1994, 144, 307-313. [CrossRef]

63. Singleton, V.L.; Rossi, J.A. Colorimetry of Total Phenolics with Phosphomolybdic-Phosphotungstic Acid Reagents. Am. J. Enol. Vitic. 1965, 16, 144-158.

64. Lange, B.; Lapierre, C.; Sandermann, H. Elicitor-Induced Spruce Stress Lignin—Structural Similarity to Early Developmental Lignins. Plant Physiol. 1995, 108, 1277-1287. [CrossRef] [PubMed]

65. Loader, N.J.; Robertson, I.; Barker, A.C.; Switsur, V.R.; Waterhouse, J.S. An improved technique for the batch processing of small wholewood samples to $\alpha$-cellulose. Chem. Geol. 1997, 136, 313-317. [CrossRef]

66. Pinheiro, J.; Bates, D.; DebRoy, S.; Sarkar, D. Nlme: Linear and Nonlinear Mixed Effects, 2020.

67. Esbensen, K.H.; Swarbrick, B.; Westad, F.; Whitcomb, P.; Anderson, M. Multivariate Data Analysis: An Introduction to Multivariate Analysis, Process Analytical Technology and Quality by Design, 6th ed.; CAMO Software AS: Oslo Magnolia, TX, USA, 2018; ISBN 978-82-691104-0-1.

68. Zhao, N.; Wu, Z.; Zhang, Q.; Shi, X.; Ma, Q.; Qiao, Y. Optimization of Parameter Selection for Partial Least Squares Model Development. Sci. Rep. 2015, 5, 11647. [CrossRef] [PubMed]

69. Kopačková, V.; Ben-Dor, E.; Carmon, N.; Notesco, G. Modelling Diverse Soil Attributes with Visible to Longwave Infrared Spectroscopy Using PLSR Employed by an Automatic Modelling Engine. Remote Sens. 2017, 9, 134. [CrossRef]

70. Heise, H.M.; Damm, U.; Lampen, P.; Davies, A.N.; McIntyre, P.S. Spectral Variable Selection for Partial Least Squares Calibration Applied to Authentication and Quantification of Extra Virgin Olive Oils Using Fourier Transform Raman Spectroscopy. Appl. Spectrosc. 2005, 59, 1286-1294. [CrossRef]

71. Eisele, A.; Lau, I.; Hewson, R.; Carter, D.; Wheaton, B.; Ong, C.; Cudahy, T.; Chabrillat, S.; Kaufmann, H. Applicability of the Thermal Infrared Spectral Region for the Prediction of Soil Properties Across Semi-Arid Agricultural Landscapes. Remote Sens. 2012, 4, 3265-3286. [CrossRef]

72. Asner, G.P.; Martin, R.E.; Anderson, C.B.; Knapp, D.E. Quantifying forest canopy traits: Imaging spectroscopy versus field survey. Remote Sens. Environ. 2015, 158, 15-27. [CrossRef]

73. Kokaly, R.F.; Rockwell, B.W.; Haire, S.L.; King, T.V.V. Characterization of post-fire surface cover, soils, and burn severity at the Cerro Grande Fire, New Mexico, using hyperspectral and multispectral remote sensing. Remote Sens. Environ. 2007, 106, 305-325. [CrossRef]

74. Serrano, L.; Peñuelas, J.; Ustin, S.L. Remote sensing of nitrogen and lignin in Mediterranean vegetation from AVIRIS data: Decomposing Biochemical from Structural Signals. Remote Sens. Environ. 2002, 81, 355-364. [CrossRef]

75. Kirchgeßner, H.-D.; Reichert, K.; Hauff, K.; Steinbrecher, R.; Schnitzler, J.-P.; Pfündel, E.E. Light and temperature, but not UV radiation, affect chlorophylls and carotenoids in Norway spruce needles (Picea Abies (L.) Karst.). Plant Cell Environ. 2003, 26, 1169-1179. [CrossRef]

76. Soukupová, J.; Rock, B.N.; Albrechtová, J. Comparative study of two spruce species in a polluted mountainous region. New Phytol. 2001, 150, 133-145. [CrossRef]

77. Proe, M.F.; Midwood, A.J.; Craig, J. Use of stable isotopes to quantify nitrogen, potassium and magnesium dynamics in young Scots pine (Pinus sylvestris). New Phytol. 2000, 146, 461-469. [CrossRef]

78. Weatherall, A.; Proe, M.F.; Craig, J.; Cameron, A.D.; Midwood, A.J. Internal cycling of nitrogen, potassium and magnesium in young Sitka spruce. Tree Physiol. 2006, 26, 673-680. [CrossRef]

79. Yuan, Z.; Shi, X.; Jiao, F.; Han, F. N and P resorption as functions of the needle age class in two conifer trees. J. Plant Ecol. 2018, 11, 780-788. [CrossRef]

80. Lhotáková, Z.; Urban, O.; Dubánková, M.; Cvikrová, M.; Tomášková, I.; Kubinova, L.; Zvára, K.; Marek, M.V.; Albrechtová, J. The impact of long-term CO2 enrichment on sun and shade needles of Norway spruce (Picea Abies): Photosynthetic performance, needle anatomy and phenolics accumulation. Plant Sci. 2012, 188-189, 60-70. [CrossRef]

81. Wild, A.; Schmitt, V. Diagnosis of Damage to Norway Spruce (Picea Abies) through Biochemical Criteria. Physiol. Plant. 1995, 93, 375-382. [CrossRef]

82. Artemkina, N.A.; Orlova, M.A.; Lukina, N.V. Spatial Variation in the Concentration of Phenolic Compounds and Nutritional Elements in the Needles of Spruce in Northern Taiga Forests. Contemp. Probl. Ecol. 2019, 12, 769-779. [CrossRef] 
83. Aitkenhead-Peterson, J.A.; Alexander, J.E.; Albrechtová, J.; Krám, P.; Rock, B.N.; Cudlín, P.; Hruška, J.; Lhotáková, Z.; Hunt, R.; Oulehle, F.; et al. Linking Foliar Chemistry to Forest Floor Solid and Solution Phase Organic C and N in Picea abies [L.] Karst Stands in Northern Bohemia. Plant Soil 2006, 283, 187-201. [CrossRef]

84. Jolly, W.M.; Hadlow, A.M.; Huguet, K. De-coupling seasonal changes in water content and dry matter to predict live conifer foliar moisture content. Int. J. Wildland Fire 2014, 23, 480-489. [CrossRef]

85. Krám, P.; Oulehle, F.; Štědrá, V.; Hruška, J.; Shanley, J.B. Geoecology of a Forest Watershed Underlain by Serpentine in Central Europe. Northeast. Nat. 2009, 16, 309-328. [CrossRef]

86. Novak, M.; Holmden, C.; Farkaš, J.; Kram, P.; Hruska, J.; Curik, J.; Veselovsky, F.; Stepanova, M.; Kochergina, Y.V.; Erban, V.; et al. Calcium and strontium isotope dynamics in three polluted forest ecosystems of the Czech Republic, Central Europe. Chem. Geol. 2020, 536, 119472. [CrossRef]

87. Petrash, D.A.; Buzek, F.; Novak, M.; Cejkova, B.; Kram, P.; Chuman, T.; Curik, J.; Veselovsky, F.; Stepanova, M.; Myska, O.; et al. Spatially resolved soil solution chemistry in a central European atmospherically polluted high-elevation catchment. SOIL 2019, 5, 205-221. [CrossRef]

88. Hovi, A.; Raitio, P.; Rautiainen, M. A spectral analysis of 25 boreal tree species. Silva Fenn. 2017, 51. [CrossRef]

89. Rock, B.N.; Williams, D.L.; Moss, D.M.; Lauten, G.N.; Kim, M. High-spectral resolution field and laboratory optical reflectance measurements of red spruce and eastern hemlock needles and branches. Remote Sens. Environ. 1994, 47, 176-189. [CrossRef]

90. Dengel, S.; Grace, J.; Aakala, T.; Hari, P.; Newberry, S.L.; Mizunuma, T. Spectral characteristics of pine needles at the limit of tree growth in subarctic Finland. Plant Ecol. Divers. 2013, 6, 31-44. [CrossRef]

91. Wu, Q.; Song, C.; Song, J.; Wang, J.; Chen, S.; Yu, B. Impacts of Leaf Age on Canopy Spectral Signature Variation in Evergreen Chinese Fir Forests. Remote Sens. 2018, 10, 262. [CrossRef]

92. Lhotáková, Z.; Brodský, L.; Kupková, L.; Kopačková, V.; Potůčková, M.; Mišurec, J.; Klement, A.; Kovářová, M.; Albrechtová, J. Detection of Multiple Stresses in Scots Pine Growing at Post-Mining Sites Using Visible to near-Infrared Spectroscopy. Environ. Sci. Process. Impacts 2013, 15, 2004-2015. [CrossRef]

93. Daughtry, C.S.T.; Biehl, L.L.; Ranson, K.J. A new technique to measure the spectral properties of conifer needles. Remote Sens. Environ. 1989, 27, 81-91. [CrossRef]

94. Hovi, A.; Mõttus, M.; Juola, J.; Manoocheri, F.; Ikonen, E.; Rautiainen, M. Evaluating the performance of a double integrating sphere in measurement of reflectance, transmittance, and albedo of coniferous needles. Silva Fenn. 2020, 54. [CrossRef]

95. Noda, H.M.; Motohka, T.; Murakami, K.; Muraoka, H.; Nasahara, K.N. Accurate measurement of optical properties of narrow leaves and conifer needles with a typical integrating sphere and spectroradiometer: Measuring Optical Properties of Narrow Leaves. Plant Cell Environ. 2013, 36, 1903-1909. [CrossRef] [PubMed]

96. Verrelst, J.; Malenovský, Z.; Van Der Tol, C.; Camps-Valls, G.; Gastellu-Etchegorry, J.-P.; Lewis, P.; North, P.; Moreno, J. Quantifying Vegetation Biophysical Variables from Imaging Spectroscopy Data: A Review on Retrieval Methods. Surv. Geophys. 2019, 40, 589-629. [CrossRef]

97. Ely, K.S.; Burnett, A.C.; Lieberman-Cribbin, W.; Serbin, S.P.; Rogers, A. Spectroscopy can predict key leaf traits associated with source-sink balance and carbon-nitrogen status. J. Exp. Bot. 2019, 70, 1789-1799. [CrossRef] [PubMed]

98. Nakaji, T.; Oguma, H.; Nakamura, M.; Kachina, P.; Asanok, L.; Marod, D.; Aiba, M.; Kurokawa, H.; Kosugi, Y.; Kassim, A.R.; et al. Estimation of six leaf traits of East Asian forest tree species by leaf spectroscopy and partial least square regression. Remote Sens. Environ. 2019, 233, 111381. [CrossRef]

99. Serbin, S.P.; Singh, A.; McNeil, B.E.; Kingdon, C.C.; Townsend, P.A. Spectroscopic determination of leaf morphological and biochemical traits for northern temperate and boreal tree species. Ecol. Appl. 2014, 24, 1651-1669. [CrossRef] [PubMed]

100. Masaitis, G.; Mozgeris, G.; Augustaitis, A. Spectral reflectance properties of healthy and stressed coniferous trees. iForest 2013, 6, 30-36. [CrossRef]

101. Croft, H.; Chen, J.M.; Zhang, Y. The applicability of empirical vegetation indices for determining leaf chlorophyll content over different leaf and canopy structures. Ecol. Complex. 2014, 17, 119-130. [CrossRef]

102. Drolet, G.G.; Middleton, E.M.; Huemmrich, K.F.; Hall, F.G.; Amiro, B.D.; Barr, A.G.; Black, T.A.; McCaughey, J.H.; Margolis, H.A. Regional Mapping of Gross Light-Use Efficiency Using MODIS Spectral Indices. Remote Sens. Environ. 2008, 112, $3064-3078$. [CrossRef]

103. Petisco, C.; García-Criado, B.; Mediavilla, S.; De Aldana, B.R.V.; Zabalgogeazcoa, I.; García-Ciudad, A. Near-infrared reflectance spectroscopy as a fast and non-destructive tool to predict foliar organic constituents of several woody species. Anal. Bioanal. Chem. 2006, 386, 1823-1833. [CrossRef]

104. Schlerf, M.; Atzberger, C.; Hill, J.; Buddenbaum, H.; Werner, W.; Schüler, G. Retrieval of chlorophyll and nitrogen in Norway spruce (Picea abies L. Karst.) using imaging spectroscopy. Int. J. Appl. Earth Obs. Geoinf. 2010, 12, 17-26. [CrossRef] 